Preprints of the

Max Planck Institute for

Research on Collective Goods

Bonn 2006/1

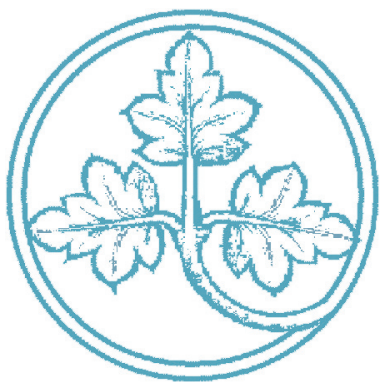

The Difficult Reception of Rigorous Descriptive Social Science in the Law

Christoph Engel

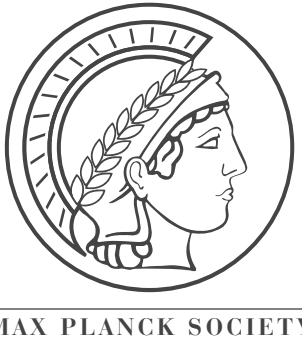




\section{The Difficult Reception of Rigorous \\ Descriptive Social Science in the Law}

\section{Christoph Engel}

I. $\quad$ Research Question 2

II. Illustrations from Legal Practice $\quad 4$

III. Problems with Integrating Rigorous Descriptive Social Science into Law 5

1. Lack of Expertise 6

2. Loss of Judicial Power $\quad 7$

3. Implicit Value Judgments $\quad 7$

4. Analysis vs. Decision Making 9

a) Object of Study 9

b) Openness to Implicit Knowledge 10

c) Different Disciplinary Norms 11

d) Falsification vs. Hermeneutics 11

e) Different Attitude Towards Certainty 12

f) Different Attitudes Towards Social Construction 13

g) Objectivity vs. Truth 14

h) Role of Judgement 14

i) Observer vs. Actor 16

5. Definition of the Situation 17

6. Practical Reasoning 17

7. Psychology of Judicial Decision Making 19

a) Phenomenology 19

b) Holistic Thinking 20

c) Combination of Several Decision Modes 21

d) Impact of Formal Social Science on Judicial Decision Making 21

8. Doctrinal Impediments 22

9. Procedural Impediments 23

10. Autonomy of the Legal System 26

11. Fuzzy Goal Function of the Law 28

IV. Benefits from Integrating Rigorous Descriptive Social Science into Law 29

V. The Art of Integrating Formal Social Science into Law 31

VI. References 34

* I I am grateful to Martin Hellwig and to Stefan Tontrup for their comments on an earlier version, to Lena Heuner for research assistance and to Darrell Arnold for the linguistic trimming of the paper. 


\section{Research Question}

Iudex non calculat. For most lawyers, the proverb settles it. Formal methods are none of their business. This holds for explicit models no less than for quantitative empirical methods. Actually, the use of mathematics only makes the challenge patent; informal, but rigorous conceptual and empirical tools from the social sciences fare no better. Interestingly, this reticence is often even to be found in lawyers, who, in principle, are quite open to findings or insights from the neighbouring disciplines. What they learn from interaction with social scientists mystically transforms into topical arguments. On that path, all the methodological caveats from the science of origin get lost.

Social scientists, when they become aware of this legal practice, usually react with disdain: Lawyers are no better than laypeople. They lack sophistication. Is the law a science at all? This paper claims: Disdain is overly simplistic. Simply turning lawyers into social scientists would be inappropriate. Just more and better training will not do. Rather, the more rigorous the methods, the more careful the interface between law and the social sciences must be designed. This is challenging, but not impossible to do.

The interface between the law and the social sciences is, of course, not a new topic. There have been violent battles, like the one about cost-benefit analysis in the US (HEINZERLING 1998; McGarity 1998; Adler and Posner 1999; AdLer and Posner 2000; Posner 2000b; SunSTEIN 2000b; SYMPOSIUM 2000), or about law and economics in Germany (FEZER 1986; FEZER 1988; OTT and SCHÄFER 1988; KIRCHNER 1991). There is a rich literature discussing legal methodology, once the law is defined as a governance tool (see only SCHUPPERT 1993; SCHMIDTAßMANN and HofFMANN-RIEM 2004). A couple of years ago, I myself wrote a programmatic piece, pleading for "the law as applied social science" (ENGEL 1998b). In my own substantive work, I have routinely used concepts from the social sciences. In so doing, I have tried out many different formats, ranging from doctrinal argument (e.g. ENGEL 2004d) over advice for legal policy-making (e.g. ENGEL 2002a) to reconstructions of governance tools by way of a formal model (ENGEL 2006).

Against this backdrop, the paper wants to make a specific contribution by deliberately narrowing down the field of observation. This is not another exercise in putting welfare economics into perspective (on this see only THOMPSON, ELLIS et al. 1990). It is taken for granted that there are normative goals competing with allocative efficiency, and that the law might want to trade some efficiency for purposes of redistribution, fairness or identity, to name only some of the competitors (more from ENGEL 2001b). The focus is thus not on the prescriptive side, but on the descriptive side of social science (on the distinction see VAN AAKEN 2003). The law relies on a social science to learn more about the regulated issue, be it in terms of facts, or of analytic tools (on this distinction SCHMIDT-AßMANN 2004b:399). The focus is thus on the empirical, on the explanatory and on the predictive side of social science. 
At first blush, one should think that this side of social science is much less critical for the law than the normative side. Why is it that, nonetheless, resistance against taking the social sciences seriously for descriptive purposes is no less pronounced? This could, of course, in and of itself be the topic of a study by a social scientist. An economist could flesh out the incentive effects of opening up legal discourse to the language and the methods of the social sciences. A political scientist could analyse the battle over methodology as a battle over power, within the discipline, but also in the legal community more generally, and in the political arena at large. A sociologist could describe traditional legal methodology as a tool for community building and enculturation. The following is informed by these perspectives. But this is a paper by a lawyer. I want to understand why so many of my colleagues are so reluctant. I want to distinguish more from less legitimate reasons for this reticence. I ultimately want to argue with my colleagues: even if I am making the case for scepticism as strong as possible, there is still room for us lawyers to take the social sciences seriously. I am thus not a disinterested anthropological observer, studying the peculiar discourse of the legal tribe. I am a member of this tribe, in all honesty arguing for a change in discourse.

If one wants to convince, one should not appear biased. Specifically, one should argue with the opposite view where it is strongest. In ideal types, a legal academic may define her task in three ways: she may contribute to the evolution of doctrine; she may advise courts and policy-makers how to make new law; and she may study legal phenomena as an outside observer. The case against openness for empirical and analytic methodology from the social sciences is strongest if one adopts the first task definition. Consequently, I am focusing on the interface between descriptive social science and the application of legal rules. Actually, the case becomes even stronger if one focuses on the customer of academic doctrinal work, i.e. the courts, administrative authorities, or the attorneys of those arguing before these legal decision makers. I do thus start form the idea that the results of legal academic work should ultimately be marketable in legal practice. I am exploring why legal practice might find it difficult to digest rigorous descriptive social science. I try, however, to show that this does not imply that descriptive social science should be banned altogether. Rather, one must carefully design appropriate interfaces. This has implications for the division of labour between legal practice and academia.

It would not be difficult to write a complementary paper, vigorously arguing for the integration of rigorous descriptive social science into law. After all, the social sciences have adopted their empirical and analytic methodologies for good reason. Rhetorically, the point could be made even stronger by confronting concrete instances of erring legal intuition with methodologically sound scientific criticism. I will not be doing that here. Basically I take it for granted that social scientists are experts in their domains, and that the quality of legal decisions could be improved if this expertise were to have an impact. For this is not where the problem is. There is, of course, sheer legal ignorance. But it is not a worthy topic for a scholarly paper. Ignorance is best combated by teaching, maybe accompanied by a little prodding and nudging. Such calls for scientific betterment will, however, not do where the reluctant discipline is raising potentially legitimate concerns. Finding out whether there are such concerns is the purpose of this paper. 
Social science is as little uniform as is law. Quite a few of the legal concerns with descriptive social science are raised by critics in these fields as well (characteristic pieces include LEAMER 1983; MCCloskey 1998; MCCloskey and ZiLiAK 2001). When social scientists are asked to give policy advice, or to help firms choose their strategies, their customers sometimes raise concerns not so dissimilar from the legal ones. Fencing the law off from the social sciences, or transforming the findings such that they become easier to digest, is therefore not the only option. Lawyers, however, will not often be in a position to insist that the descriptive input from a social science be more appropriate for their purposes. In exploring the concerns, I will therefore assume "normal" social science. Since I am interested in legal reticence, I will not explore a complementary question: would social scientists have good reason to resist being instrumentalised by lawyers?

The paper starts by illustrations from legal practice (Section II). The bulk of the paper explores the legitimacy of concerns (Section III). Thereafter, the main arguments in favour of integrating rigorous descriptive social science into law are briefly summarised (Section IV). This sketch highlights that the law must strike a balance. In the case at hand, how much is to be gained from taking formal science on board? How can the risks for the proper functioning of the law be minimised? There is no one-size-fits-all solution. Integrating formal social science into law is itself an art (Section V).

\section{Illustrations from Legal Practice}

"Lip service notwithstanding, there is surprisingly little interest in methodologically controlled empirical social science" (LEPSIUS 2005:12). "It may be doubted, however, that the methods employed in empirical social science could, or should for that matter, be easily integrated into the arsenal of jurisprudence" (see also HofFMANN-RIEM 2001:10; HoFFMANN-RIEM 2004:62 note 138). These two citations certainly offer a fair characterisation of the predominant attitude in the German legal community. As demonstrated by the law and economics (see only CoOTER and ULEN 2004) and the empirical law movements (see only KLERMAN and MAHONEY 2004), American legal academia is definitely more open. But there too, rigorous methodology from the social sciences rarely travels into actual legal decision making. The proponents of such methods proudly make claims as modest as "the law of contract has, in fact, been informed by efficiency considerations, even if judges and lawyers may have found it difficult to articulate the underlying economic premises of the law" (POSNER and ROSENFIELD 1977:89; see also VISCUSI 2001:114 and passim). If one asks those who are at the cutting edge of law and economics scholarship about its impact on legal practice, they readily admit that the courts simply do not care.

There are, however, exceptions. The willingness of the courts to rely on the natural sciences is quite pronounced (LEPSIUS 2005:4). In so doing, the courts carefully report and discuss the methodological conditions for the legally relevant findings. For instance, the German Bundesgerichtshof painstakingly investigates the findings concerning the ability to drive under the 
influence of alcohol. ${ }^{1}$ Even more revealing is a decision holding the producer liable under criminal law for having sold a timber preservative. The court says the producer has willingly taken into account that users fall ill. Not surprisingly, it was not possible to prove the exact mechanism by which the chemical impacted on users' health. This did not bother the court. The court was content with the application of the methodological standards of the pertinent natural sciences. ${ }^{2}$

Similar decisions are to be found in the jurisprudence of the Bundesverfassungsgericht. When corroborating the criminal sanctions against consuming cannabis, the court widely discussed the relevant findings from the literature. ${ }^{3}$ It did the same when regulated access to the professional care of the elderly came under attack. In this ruling, the court extensively reported statistical data and model calculations on the demographics of the Federal Republic. ${ }^{4}$ Finally, a decision by the Spanish Supreme Court is striking. It is again taken from a criminal case. The defendants had marketed contaminated edible oil. Again, causality was disputed. The court allowed statistical evidence (cf. KoEHLER and SHAVIRO 1990). "To find causality [...] it is not necessary to know the exact mechanism by which the effect has been brought about, as long as a correlation or the nexus between the relevant events could be found, and alternative causes can be excluded". ${ }^{5}$

Openness to the methodological standards of the social sciences is a different matter. One noteworthy exception stems from antitrust (cf. BöGE 2004). A couple of years ago, the European Commission ushered in a "more economic approach" to European antitrust. ${ }^{6}$ A visible sign of this is the new position of a chief economist in the Competition Directorate General. With this approach comes a greater openness to the methodology prevalent in academic economic thinking about antitrust issues (HILDEBRAND 2002; NITSCHE and THIELERT 2004). The European Court of First Instance seconded by giving the Commission greater leeway with respect to methodology. ${ }^{7}$

\section{Problems with Integrating Rigorous Descriptive Social Science into Law}

Some of the reasons for the legal reticence to rigorous social science methods are down to earth. Most lawyers lack the necessary expertise (discussed in Section 1 below). They fear that judicial power might erode (Section 2). Other reasons carry greater weight. By accepting alien methodology, lawyers might unwillingly take value judgments on board (Section 3). Most importantly, the legal task is fundamentally different from the task of a social scientist (Section 4). Related to

Bundesgerichtshof 6/28/1990, Neue Zeitschrift für Strafrecht 1990, 491, 492.

Bundesgerichtshof 8/2/1995, Neue Zeitschrift für Strafrecht 1995, 590, 591.

Bundesverfassungsgericht 3/9/1994, Entscheidungen des Bundesverfassungsgerichts 90, 145, $178 \mathrm{f}$.

Bundesverfassungsgericht 10/24/2002, Entscheidungen des Bundesverfassungsgerichts 106, 62, $73 f$.

Tribunal Supremo 4/23/1992, Cuadernos del Consejo General del Poder Judicial 1992, 69, cited from the German translation, Neue Zeitschrift für Strafrecht 1994, 37, 38.

6 White Paper on the modernisation of the rules implementing articles 85 and 86 of the EC Treaty, of April 28, 1999, § 78 (Commission Programme 99/027),

http://europa.eu.int/comm/competition/antitrust/wp_modern_en.pdf (2/11/2005).

7 European Court of First Instance 6/6/2002, Case T-342/99, §§ 58-64 - Airtours; 10/25/2002, Case T-5/02, § 119 - Tetra Laval. 
this, lawyers define the situation in a way that differs from the definitions prevalent in the social sciences (Section 5). For both reasons, practical, not theoretical, reasoning is called for (Section 6). Actually, judicial psychology responds to this need (Section 7). A further problem originates in the, usually low, compatibility of doctrinal strictures with the strictures from formal social science (Section 8). Procedural rules make it difficult to take social science on board (Section 9). The autonomy of the legal system is to be respected (Section 10). Finally, the law purposefully has a fuzzy goal function. Some of the goals beyond effective governance do not marry well with formal social science (Section 11).

\section{Lack of Expertise}

"Judges are no economists" (EIDENMÜLLER 1995:427). The bottom line is as simple as that. Even if some of them go back to class, as a famous group of American judges did, the judiciary as a body cannot be expected to possess the mathematical and statistical skills that are standard in the advanced social sciences. Neither are they trained in the rigorous methods of qualitative empirical work (see King, KEOHANE et al. 1994), or in the elaborate conceptual architecture of informal explanatory paradigms, like systems theory (for an introduction see LUHMANN 1986). In the long run, this might change. All top US law schools have faculty members with impressive modelling skills. Many of these schools have even given up teaching a general course in law and economics, since the approach has become pervasive. Nonetheless, the social sciences are bound to be permanently ahead of legal practice. Cutting-edge approaches in microeconomics, like mechanism design (FUDENBERG and TIROLE 1991), have only very rarely been applied in the law as yet. Statistical methods are only now gaining influence in the law schools (for an example see again KLERMAN and MAHONEY 2004). Behavioural law and economics is a fairly recent movement (SUNSTEIN 2000a) and so forth.

The lack of expertise may have unwanted side-effects. Reluctance may result from ignorance, rather than deep conviction. Misunderstandings are not unlikely. When first confronted with a rational choice model, most lawyers take for normative what is meant to be analytic (VAN AAKEN 2003). On the analytic side, they start debating the Homo oeconomicus assumption (at a fairly advanced level GRÖSCHNER 1998). They usually take methodological individualism for a statement about reality. It takes time before they understand the two classic arguments in defence of this methodology: even if wrong in individual cases, the assumption might still hold in the aggregate. In designing institutions, the risk of egoism might matter asymmetrically (FRIEDMAN 1953; BECKER 1976). Unless explicitly educated otherwise, lawyers may fall prey to their intuitions. Before one has seen the evidence, it in particular is hard to believe that statistics usually outperform experts (MEADOW and SUNSTEIN 2001; SUROWIECKI 2004). The main purpose of economic argument is not to pin down linear causality. Rather economists search for equilibrium. They thus aim at clarifying the interdependence between the action of several (groups of) actors. 
A last concern carries greater weight. Lawyers rightly sense that mathematics and statistics are foreign languages, as are the conceptual languages used in informal analysis. Lawyers are trained to see language as a powerful tool. They know only too well how easily language can be employed for strategic purposes. And they have seen often enough how important it is to listen carefully. If a nuance is missed, the case may well be lost. In all honesty, modellers and statisticians must admit that the pitfalls of their respective languages are no smaller in this respect. If the methods from empirical and analytic social sciences were allowed in court, those adept in these technologies would have a strategic advantage. If the issue is important enough, the opponent would react by also hiring social scientists. But this mechanism would only work if both parties could invest sufficient resources. At any rate, it would result in an arms race. More importantly, professional judges would often not have the expertise to counteract such movements.

\section{Loss of Judicial Power}

Since the formation of modern law in the Roman Empire, lawyers have always been close to power (SCHIAVONE 1991). In the US, it is the hallmark of critical legal studies to trace power politics under the guise of legal benevolence (KELMAN 1987). It is therefore not far-fetched to speculate that some lawyers might repel the social sciences because they anticipate an erosion of legal power (LEPSIUS 2005:10). Specifically, for that reason, lawyers might dislike formal methodology. It entails a double risk. Outsiders not under the control of the legal community could pass through doctrinal fences. Even worse, alien, but rigorous, methods would endow them with weapons, the effect of which the ordinary lawyer is neither able to predict nor to counteract. But, of course, maintaining the power of a profession is not a legitimate aim as such. The profession would have to show that alternative institutional arrangements serve society worse than the lawyers do.

\section{Implicit Value Judgments}

Law and economics scholars rightly spend much time and effort carrying home the distinction between positive and normative analysis. There is, of course, normative welfare economics (BAUMOL 1965; NG 2003). It is, at the least, consequentialist, if not openly utilitarian. Lawyers often have good reason to resist allocative efficiency as the only, or even as the predominant, normative goal (EIDENMÜLLER 1995). But descriptive analysis, based on methodological individualism, is a different matter (VAN AAKEN 2003). In principle, such analysis is agnostic with respect to goals for legal policy-making. It is a conceptual tool for understanding incentives and how they are changed by legal intervention.

However, in more subtle ways, methodology may be linked to normative goals. A seemingly farfetched parallel helps elucidate the point. The performance of weather forecasters in the Denver airport was tested under two conditions: in ordinary circumstances, and under experimentally induced stress. Stress had two effects. Forecasters became significantly more accurate, but also 
more risk averse. They thus sent more planes away for fear of severe weather than in the no stress condition (HAMMOND, HARVEY et al. 1992). Choosing between the concomitant risks of false positives versus false negatives is a normative question (LEVI 1962).

In the experiment, better decision quality was thus not normatively neutral. Taking the rigorous methods from the social sciences on board could have the same effect on legal decision making. Statistics are on average more accurate than experts (see again MEADOW and SunSTEIN 2001). But statistics need sufficiently large samples of quantitative data (HAYs 1994). ${ }^{8}$ Otherwise, results are not significant. Statistical accuracy thus comes at a double price. The investigation is biased in favour of quantitative data, at the expense of qualitative analysis. Moreover, statisticians will seek out large samples, at the expense of local effects. This is not a merely theoretical concern. It is at the heart of the American dispute over cost-benefit analysis. In order to increase rationality and political control, the Environmental Protection Agency is under an obligation to carry out such analysis. ${ }^{9}$ Critics have pointed to the fact that this has resulted in giving the measurable death toll excessive weight in policy-making. Other deteriorations of health are not so easily quantified. Even less do non-health risks, like the overall impact on nature as a complex system, lend themselves to quantification (HEINZERLING 1998; DrieSEN 2000; ACKERMAN and HEINZERLING 2002).

Rigorous modelling may have a similar effect. It indubitably increases accuracy in assessing causal relationships and it helps pinpoint interdependencies. The rational choice model is a powerful tool for understanding the mechanics of strategic interaction. For many social problems, this is an elucidating perspective. However, strategic interaction is but one aspect of social life. People do not only care about their individual well-being, however defined. It is equally justified to portray them as social animals (ARISTOTLE and KENYON 2003). As such, they care about relative position, not only about absolute utility (TVERSKY and SIMONSON 1993). This is how the empirically strong fairness inclinations differ from preferences (FEHR and SCHMIDT 2000). Also, not all social problems are exclusively motivational in nature. Often, forging a joint understanding of the situation is at least as important (HEINER 1983; ENGEL 2005). Under real-life conditions, analysing the underlying conflict of interests is often not paramount. It would only matter once open, violent conflict has been tamed (FARNSWORTH 2000; ENGEL 2003).

Such objections would be less important, were there sufficiently powerful conceptual tools for drawing alternative analytic pictures. Admittedly, due to developments like behavioural economics, the situation is improving (see e.g. FEHR and SCHMIDT 1999; TIROLE 2002). But it is still far from balanced. This is not surprising. Scientific disciplines are social endeavours. This makes them path dependent (KUHN 1962). Economics has been extreme in this respect. For more than a century, buying into the rational choice model has been the easiest way to make a career in the field. This deliberate narrow-mindedness has resulted in the outstanding quality of rational

8 KING, KeOHANE and VerBA Designing Social Inquiry (1994) do, however, demonstrate how much of conceptually controlled inference may travel to situations of "small N", i.e. situations with small samples.

9 Sec. 812 Clean Air Act, see also Unfunded Mandates Reform Act of 1995, Pub. L. No. 104-4, § 202, 109 Stat. 48 (codified at 2 U.S.C. $§ 1532$ (1995)), further extending the scope of cost-benefit analysis. 
choice analysis. It is unmatched by any alternative approach in the social sciences. This explains why rational choice has been so successful in invading not only law, but also political science (e.g. SCHARPF 1997) and sociology (e.g. COLEMAN 1990). Ironically, excellent quality is nowadays the strongest impediment to embracing rational choice methodology in law. When lawyers do so, they must strive hard to balance out rational choice findings. The competing aspects or concerns can hardly ever be formulated in comparable quality.

\section{Analysis vs. Decision Making}

Much of the reluctance to integrate rigorous methodology from the social sciences into legal reasoning may be put down to one difference: social scientists and lawyers have different tasks. Social scientists want to explain social phenomena. They want to test their hypotheses. Occasionally, they also engage in prediction. Lawyers, however, want to take decisions. Of course, not all lawyers have decision-making power. Judges, administrative authorities and the legislator do. Counsels and the Attorney General take part in a formal procedure that leads to decision making. When they help the parties draft legal instruments, lawyers anticipate future authoritative decisions, or they prepare to prevent them. A similar subsidiary role for future decision making is also assumed by all those academic lawyers who do doctrinal work.

The task difference has many facets. Both tasks have different objects (treated in Section a below). In decision tasks, implicit knowledge plays a legitimate role (Section b). The different tasks are accompanied by different disciplinary norms (Section c). Methodological orientations differ profoundly. While most social science aims at falsification, most legal science is hermeneutical (Section d). The social sciences and law differ in their attitudes towards certainty (Section e) and social construction (Section $\mathrm{f}$ ). While the majority of social scientists take objectivity to be the supreme goal, lawyers predominantly pursue truth (Section g). This difference translates itself into a very different role of judgment (Section h). While social scientists are observers, most lawyers explicitly or implicitly are actors (Section i). The differences play themselves out with respect to all the elements of the process of decision making (Section $\mathrm{j}$ ).

\section{a) Object of Study}

The theory/practice divide has many facets. It starts with the object of study. Ultimately, all legal work must be helpful in deciding cases. It is thus a real-life conflict that determines relevance. The more rigorous the method, the more remote the concrete conflicts become from work in the social sciences. As illustrated by most papers published in the esteemed economics journals, the standard topic in the social sciences is one precisely defined causal or interdependent relationship. Metaphorically speaking, a social scientist excels in making everything black or white. Contrary to this, lawyers are masters in handling superimposed shades of grey.

Precision comes at a price. "The best theory depends on one's trade-off between parsimony and fit" (HARLESS and CAMERER 1994:1285). There is thus a trade-off between quality and scope. 
High-level precision results from decontextualisation. All models rest on assumptions. They need not be counterfactual, but they are bound to be less complex than the real-life phenomenon under study. All social science is an exercise in strictly controlled partial analysis. Sharp conceptual tools from the social sciences allow us to see implications that would remain fuzzy if not invisible otherwise. Mathematics in particular permits us to precisely handle a degree of complexity unmatched by verbal discourse. Take marginal analysis, or the analysis in n-dimensional space as illustrations (more from SIMON and BLUME 1994). But along with mathematical formulation, many of the nuances of the real-life phenomenon get left aside. Consequently, mathematical modelling, like any other rigorous analytic method, imposes a stricture on legal decision making that is absent in the traditional, doctrinal mode. Of course, nuances might come back if several models are applied to one and the same phenomenon. But this requires a level of expertise unlikely in lawyers, and often not present in social scientists either. When they adopt social science methods, lawyers thus run the risk of defining the problem in an inappropriately narrow way. They are in danger of trading macro adequacy for micro precision.

A related point is this: most social scientists are better at sophistication in modelling than they are at the art of modelling (for a nice exception see HALLERBACH and SPRONK 2002). Their disciplinary background tends to pay them a smaller premium for sensitivity with respect to ecological validity and robustness. This may lead to an inappropriate focus on the existing, welldeveloped models. Typically, modellers are not particularly inclined to develop new models from scratch in order to capture a hitherto neglected, but ecologically important, aspect of reality.

\section{b) Openness to Implicit Knowledge}

Most people successfully navigate their social relations with very few if any conceptual tools from the social sciences to support them. This by no means implies that these conceptual tools are wrong or inappropriate. But the observation is evidence of the fact that people know many things implicitly that social scientists have been able to couch in rigorous terms. In this respect, lawyers are typically like laypeople. Very often, when the social sciences come up with a new brilliant insight, some lawyers grumble: we knew it all along. Of course, with precise terms, one understands a phenomenon much better (COWAN, DAVID et al. 2000). Also, the fact that some lawyers in some conflicts have found it useful to bring forward an argument does not mean that it has become the acquired wisdom of the legal community. But the observation has a disturbing implication. The lawyers, and laypeople for that matter, knew it even before the social sciences had forged the tools. There is no reason to believe in the impossibility of further progress in the social sciences. Consequently, openness to implicit knowledge insures the law against falling prey to the current inabilities in the social sciences. More disturbingly even, there may be a trade-off between precisely handling what is already understood, and neglecting what is not. The higher the premium on methodological rigour in the law, the more difficult it becomes to harness the existing implicit knowledge to improve decision quality. 


\section{c) Different Disciplinary Norms}

Science is a social endeavour; the point has already been made. It has a further implication. All social interaction relies on social norms (MARCH and OLSEN 1989; POSNER 2000a). Science is no exception to this. Disciplinary norms provide individual scientists with a benchmark. For instance, economists learn that the easiest way to earn themselves praise and a career is with advanced mathematical modelling. Their discipline thus teaches them to develop a taste for conceptual high-tech. When they select a topic, they choose it such that it allows them to demonstrate their modelling skills. The professional norm for the law is different. It is to treat the parties as best one can.

Along with this goes what has long been called professional deformation (LANGEROCK 1915). Having recourse to the categories dominant in one's field is no longer a conscious decision. Professional training has endowed the individual with a selection bias. For instance, a good economist becomes hyper-sensitive to incentive problems. After a while, it becomes difficult for her to see the world through a different lens. The social sciences themselves are rightly not too much concerned with such observations. Ultimately, such blinkers may even spur disciplinary progress. But for the decision-making task of the law, bias and narrow-mindedness are much less acceptable.

\section{d) Falsification vs. Hermeneutics}

The difference between explanation or prediction and decision making translates itself into a fundamental difference in methodology. At the heart of the scientific method is falsification (POPPER 1935). The standard design is a hypothesis, derived from a thorough theoretical framework, and tested empirically. Predictions are derived from hypotheses tested in other contexts. Recently, there have been attempts to reintroduce hermeneutics into the social sciences. But this is a vigorously disputed affair (MANTZAVINOs 2005). The law could not be more different. Many lawyers may not have heard of the term, let alone read the philosophical classics (canonical DiLthey 1923). But most of them have had access to disciplinary adaptations (remarkable ENGISCH 1983).

Most importantly, however, hermeneutics is what lawyers are doing day to day when applying doctrine. This is most obvious in the civil law countries. Here, the typical source of law is statute. The general, abstract rule is applied to the case. The case is bound to possess many more features than are relevant for the rule. Actually, solving the case is an exercise in looking back and forth between the body of rules and the features of the case. A decision is reached when both can be matched by what legal methodology calls a syllogism. Actually, doctrine in the common law countries is not fundamentally different. The only difference is this: in a first step, the abstract rule must be distilled from previous decisions.

Hermeneutics is fundamentally different from falsification. Hermeneutics is a matching exercise. In going through the hermeneutical circle, both the (statutory) text and the facts of the case re- 
main fairly flexible. It is only after the decision maker has settled down for one specific match between a certain reading of the text and a certain selection of the facts that the relationship between text and facts can be exactly described. The chosen match is almost never just right; it is the best this legal actor has been able to come up with. After the fact, it may not seem difficult to integrate descriptive methods from the social sciences. They show up at a precise point of either the establishment of the relevant facts, or the interpretation of the pertinent rules. But for the hermeneutical method, process is at least as important as outcome. And the characteristic rigour of descriptive social science methods squares poorly with hermeneutical process.

\section{e) Different Attitude Towards Certainty}

The different disciplines assume different attitudes. The attitude towards certainty may be characterised as follows: law starts from the assumption of fallible certainty, whereas the social sciences are built on the idea of methodologically controlled degrees of uncertainty. A lawyer takes for granted that her decision may be false. But she takes the decision nonetheless, and she is trained to present it as final - for the time being. It may be overturned by higher courts. The legislator may change the decisive rule, such that similar cases will be decided differently in the future. The same may happen if jurisprudence develops. But none of this makes the original decision less binding, and the judge less convinced of having found the correct solution to the case.

The different attitude in the social sciences is best characterised by a statistical test. Its very mechanics are built on an attempt to falsify. If the hypothesis is that A causes B, the statistical test runs as follows: assume that $\mathrm{A}$ is irrelevant for $\mathrm{B}$. Make an experiment with two treatments. In treatment $1, \mathrm{~A}$ is present. In treatment $2, \mathrm{~A}$ is absent, all other things being equal. If $\mathrm{A}$ is indeed irrelevant, results in both experiments should be similar. The nul hypothesis of irrelevance is refuted when two conditions are met: There is indeed a difference in outcome. It is sufficiently unlikely that this difference results from chance. Actually, the standard test of statistical significance requires that the probability that chance is the cause of the difference be at or below 5 percent (HAYs 1994:chapter 7). Note that the result is openly tentative. The statistical test is taken to be successful if there is a 5 percent probability that A does not cause B. ${ }^{10}$

Falsification suits scientific purposes well. Science is built on the idea of permanent progress. Today's achievements are meant to be tomorrow's errors, to be overcome by better science. If it is to have an effect on social interaction, the law cannot allow itself to be equally magnanimous. The law's addressees must be able to believe that they are treated correctly by legal authorities. In people's perception, wrong decisions must be rare instances of mistakes. Legal remedies are not seen as yet another try. They are precautionary measures by the legal order to restore justice, should it have been violated by the lower instances. Influential legal philosophers go even one step further. They insist on the regulative idea of the one correct solution to every case

10 Actually, the test as described does not show causality, but only a correlation between A and B. If there is nothing but this test, it is equally likely that B has caused A, not the other way round. 
(DWORKIN 1977). Most professional lawyers nowadays are more sceptical. They have too often seen an astute attorney prevail where the party he represents should have lost. But at least legal rhetoric could not possibly give up the idea of right and wrong decisions. This is one reason why it is dangerous to adopt a methodology that makes the remaining uncertainty patent.

\section{f) Different Attitudes Towards Social Construction}

There is good reason to believe that, in actuality, all attempts at understanding reality only generate social constructions (see only BERGER and LUCKMANN 1967). Quite a number of social scientists take this insight as the very starting point of their work. They analyse discourse, since they think this is more revealing than looking at "fundamentals" (e.g. RisSE 2000). The majority of social scientists do not go that far. Actually, many of them do even fight constructivism fiercely. Implicitly, however, most of them have bought into the constructivist programme. They no longer believe that the falsification endeavour will eventually reveal the truth. Rather, they follow those philosophers of science who insist on the historical contingency of scientific paradigms (programmatic KUHN 1962). This stance makes sense if one has experienced the fundamentally social character of all science. In the words of Sir Isaac Newton: scientists are standing on the shoulders of giants.

The idea that all understanding is constructivist is not alien to lawyers. But for them, the canonical input to construction comes from different sources. They are predominantly faced with the epistemic problem when assessing the particulars of a case. Plaintiff claims the contract has been concluded by handshake. Defendant claims he simply greeted a neighbour. There have been no witnesses. Plaintiff loses the case since the burden of proof is on him. Note that the parties may well have agreed on the alleged contract. But if a fact is disputed, the court will only take it into account if formal proof has been given. Procedural rules on who has the burden of proof thus are a tool for openly constructing reality.

Social construction in the law does not stop here. Frequently, the legal community shares an understanding of a social problem regulated by law. This is particularly likely if a line of jurisprudence has started with a leading case. Usually, the graphic conflict underlying this case shapes the understanding of the issue for the future. This is one reason why "hard cases make bad law", as Oliver Wendell Holmes famously put it. The effect is scaled up if a set of general rules is built on the specifics of one field of application. For instance, the general rules of German administrative law were originally developed with an eye to police encroachment upon freedom and property (MAYER 1895). The major revisions of these rules at the end of the 20th century were largely in response to environmental law (SCHMIDT-AßMANN 2004a).

Although both the social sciences and law are thus open to social construction, they are so in very different ways. Scientific paradigms are extremely stable. The only way to overcome them is with a "scientific revolution" (KUHN 1962). Those economists who no longer believe in the rational choice model have to experience the zeal and the aptitude of the majority in defending the citadel. Contrary to this, the legal constructions of reality are much more flexible. If plaintiff 
finds a witness for the conclusion of the contract before the court ruling becomes binding, he may successfully appeal. The influence of the leading case on lawyers' mindsets may be overcome by a new, equally graphic case. One field of reference may oust its predecessor and mould the general rules according to its own needs. This is what social security lawyers are currently trying to do with German administrative law (e.g. AxER 2000). Put differently, the law is not only acquainted with social construction. It also has its disciplinary routines for getting rid of it. This makes it difficult for the law to buy into the explicit or implicit constructions that come with the methodology of the respective social sciences.

\section{g) Objectivity vs. Truth}

If they are not into discourse analysis, most social scientists would only grudgingly admit that they are engaged in social construction at all. If asked for the professional standard, most of them would say: objectivity. This is at least how they justify far-reaching decontextualisation and replicability as standards in experimentation. There is good reason to argue with all these (e.g. LEAMER 1983). The philosophical counterclaim is the already mentioned idea that all science is social in nature (see again KUHN 1962). In more pragmatic terms, the history of sciences demonstrates how costly the strict goal of objectivity actually is. These critics rightly insist on the importance of science as practice for scientific progress (DASTON 1999). But when they adopt the rigorous methods from the social sciences, lawyers inevitably buy into the prevalent belief in objectivity.

It matches poorly with legal decision making. The most obvious difference is to be found in court procedure. In many countries, the ultimate criterion for the assessment of facts is not objective truth, but the subjective conviction of the judge or jury. The French have coined the term conviction intime for this (more from DEMOUGIN and FLUET 2005); (see also SchULZ 1992).

\section{h) Role of Judgement}

Many lawyers believe that formal methodology and judgement are opposites. This is not true. An econometrician permanently exercises judgement: when composing the sample; when defining the probability model against which the data is tested ${ }^{11}$; when cleaning the sample from outliers; when selecting the robustness checks, and so forth. Likewise, a modeller exercises a good deal of judgement: Which aspect of the real-world problem lends itself to rigorous modelling? Is there a standard model that helps make the point? Which are the best assumptions? Judgment thus is entailed in the already mentioned art of modelling. There is, however, a pronounced difference between judgment in the descriptive social sciences and judgment in legal decision making. In formal analysis, judgment is mainly upfront. It is in the setup of the analysis, not in the analytical mechanics. In law, however, judgment is on line. Lawyers are trained to check each and every substantial and procedural move while they are taking it. If it appears to lead the final outcome astray, there is always a doctrinal degree of freedom to readjust things. 
The statement needs qualification. In science, no less than in law, one should distinguish the context of discovery from the context of representation (POPPER 1935:§ 1 I 3; ZIMAN 2000; ENGEL 2004a). If one is interested in science as a practice, one is very likely to find on line judgment. The scientist changes the design on the fly when it dawns on her that the original idea is doomed to failure. The actual difference is thus in the context of representation. The scientific community expects a clean paper. The legal community, however, is prepared to read the major judgmental interventions in the written reasons. Legal judgment is thus not exercised in camera. Discussing judgment is the main purpose of the professional legal discourse. The more law opens itself up to the methodology of the social sciences, the more this disciplinary practice will have to change.

A related point concerns creativity. Of course, all academic work is about creativity. If there is nothing new in an academic product, it is not worth being published. But creativity has a very different status in the two contexts. In a standard product from the social sciences, there is one new idea. It drives the paper. In the introduction, the author explains why the point is important in the broader framework of the discipline. The core of the paper presents the idea in the necessary detail. Often, the conceptual claim is also tested empirically. Put differently, in such a paper, creativity is mainly exercised before the actual work starts. In doctrinal legal work, creativity is ubiquitous. A single case may require a lawyer to take dozens of subtle moves. In all but the most simple cases, the final product is idiosyncratic. Creativity is needed on many of the doctrinal bifurcations, and even more so in the composition of the entire path to the result. If formal methodology is introduced into legal decision making, these regular openings for creativity would disappear.

The different attitude towards judgment and creativity translates itself into different disciplinary standards for elegance. Again, lawyers tend to believe that they are the only ones who have a professional taste for beauty. To them, mathematical exposition is bloodless technocracy. They are highly surprised when they hear mathematicians, or social scientists for that matter, talk about the elegance of a proof. Yet, in the law, beauty is a very different animal. It may be found in the composition of the decision or of a manuscript. But it is above all the beauty of the language that is admired. For a lawyer, rhetoric does not earn her blame, but praise. Lawyers are educated to win over their public with whatever linguistic means they deem fit. This cultural trait is quite functional. It stems from the fact that legal decision making is open to whatever argument seems relevant. This not only holds for normative claims; it is relevant for the presentation of the decisive facts as well. The openness to rhetoric goes back to the need to generate acceptance for the decision. This would become much more difficult were the law to use formal language.

Finally, the different role of judgment has an effect on the characteristic objects of trust. Scientists trust method, lawyers trust judgment. Consequently, scientists do not primarily doubt the final outcome. It logically follows from painstakingly applying method. Method thus determines the degree of reliability in an intersubjective way. In contrast to this, lawyers primarily have doubts about the adequacy of the final outcome. Their trained reflex is this: the outcome may 
well be wrong, despite the fact that no methodological mistakes have been committed. The hermeneutical method provides so much leeway that it cannot itself guarantee the acceptability of the outcome. If they were to embrace rigorous methodology from the social sciences, the lawyers would have to change their attitude towards methodology. They would have to start discussing decision quality, and the assessment of the facts in particular, in terms of methodology, not only in terms of the appropriateness of the outcome. In the long run, this might be feasible. But it would require a long period of collectively learning how to maintain the judgmental component that is fundamental to legal decision making.

\section{i) Observer vs. Actor}

Social scientists are observers, lawyers are actors (on the distinction see SPENCER-BROWN 1969). This is obvious for practising lawyers, but it typically also holds for academic lawyers. When they do doctrinal work, legal practice is not merely an object of study for them. They conceive of themselves as part and parcel of the legal community.

The ultimate goal of good science is better understanding. The ultimate goal of good legal practice is better decision making. Of course, good decision making requires understanding the issue at hand. But for practising lawyers, all understanding is part and parcel of the hermeneutical exercise. It is only pursued in the interest of rendering an acceptable decision. Consequently, for a legal actor, "a contribution to the understanding of" is a useless thing. This, however, is the best rigorous methodology can yield. Moreover, legal actors must assume responsibility for their decisions. Again, this also holds for legal academics. If they change their opinion, their colleagues ask for sufficient justification. If there remains doubt, they lose credit in the field. Personal responsibility for an outcome does not marry well with rigorous methodology. In science, it would be difficult to defend a methodological blunder by a satisfactory outcome. This, however, is what lawyers are rightly expected to do. One may even push the point one step further. All legal decision making is inherently political. Consequently, in the law, generic knowledge is instrumental. It is used to the extent that it serves the politically legitimate purpose. If social scientists are caught doing the same thing, they are rightly criticised (WEBER 1967). If they adopt the methodology from the social sciences, lawyers are also likely to inherit the aversion against policy-making. This would be contrary to their decision task.

Related to this, science rightly assumes strategic interaction away. There are strict moral rules about scientific practice, and credible sanctions in the case of scientific misconduct. In legal procedure, however, strategic interaction is taken for granted. This also holds for the way academic work is introduced into procedure. If a law professor writes an opinion on behalf of one of the parties, she may not be openly partial. But everybody expects her to explore, if not extend, the doctrinal limits to the benefit of the party represented. Again, if social science methodology were introduced into legal decision making, it would be hard to prevent the strict moral rules from being applied as well. That would, however, be dysfunctional in the legal context. 


\section{Definition of the Situation}

Decisions are meant to change reality. Reality is never as well-behaved as problems must be if they are to be analysed formally (OAKSFORD and CHATER 1998; GIGERENZER, TODD et al. 1999; BRUNSWIK, HAMMOND et al. 2001). Specifically, formal analysis presupposes a defined problem. There may be uncertainty. Even the probabilities of the possible outcomes may be unknown. But, at the very least, the problem space must be known (KNIGHT 1921). This is not the world of the law. It is best at handling unprecedented or ill-understood problems in an imperfect, but still satisfactory, way. From centuries of experience, law knows that problems and our understanding of them are permanently changing. All legal decisions are best approximations, given the current state of understanding. The introduction of rigorous social science methods might tempt the law to shift to well-defined problems.

\section{Practical Reasoning}

The sceptical attitude towards the introduction of methodological rigour into legal decision making is supported by a discussion at the borderline between philosophy and psychology. It typically goes by the name of theoretical versus practical reasoning (for a recent overview see MANKTELOW 2004). Logicians have been alarmed by examples like the following (KENNY 1978):

"I'm to be in London at 4.15 .

If I catch the 2.30, I'll be in London at 4.15.

So I'll catch the 2.30."

To any non-logician, this line of argument makes perfect sense. Yet it is based on a patent logical mistake. In the syllogistic language of logicians, the argument can be written as follows:

"q; if p then q; therefore p".

Many epistemologists have been convinced by examples of this kind (more from ATKINSON, BENCH-CAPON et al. 2004) that reasoning with the aim of decision making is different from reasoning with the aim of understanding (HARMAN 1995). Both lead to different outcomes and to different norms for assessing them.

In practical reasoning, preferences are not a given; rather they are a result (SEARLE 2001). Practical reasoning is uncertain and tentative (WALTON 2001:141). It openly eschews formal logic (WALTON 2001:141 and passim). Wishful thinking is perfectly proper in practical reasoning, as is arbitrary choice aimed at overcoming an impasse (HARMAN 2004). In practical reasoning, the redundancy of justifications is a value. It allows us to increase the plausibility of the result (JOSEPHSON and JOSEPHSON 1994). Practical reasoning is contextual. The reasons generated that way only hold for the context for which they have been developed (WALTON 2001:147). Practi- 
cal reasoning is elliptical, meaning that elements of the justification are omitted on purpose. Thereby, the speaker hopes to trigger favourable, but different, associations in the listener (AtKinson, BENCH-CAPON et al. 2004:89).

One strategy of practical reasoning has received the somewhat mystical name abduction (HARMAn 1965; PeIRCE and KeTNer 1992). "The conclusion drawn by abductive inference is an intelligent guess. But it is still a guess, because it is tied to an incomplete body of evidence. [...] It is subject to being overturned by further evidence in the case" (WALTON 2001:143). Thereby, abduction is "defeasible" (WALTON 2001:145). Abduction is "forming a plausible hypothesis that explains a given set of facts or data" (WALTON 2001:143). Every lawyer will recognise this as her day-to-day practice. A good example is witnessed testimony. "Our confidence in his testimony is supported by the failure of there to be any other plausible explanation than that he actually did witness the situation he describes" (WALTON 2001:144). This is an example for a "lackof-knowledge inference" (WALTON 2001:145). More generally, abductive reasoning starts from the rebuttable presumption that the situation is standard (WALTON 2001:146). Therefore, abduction is not based on rules of the type "all A are B". Rather, "abductive inferences are derived from the way things can normally be expected to go in a familiar kind of situation" (WALTON 2001:146). Abductive reasoning does not result in general principles, but in issue-specific judgments of likelihood (WALTON 2001:148).

A second strategy of practical reasoning is equally close to the law. It goes by the more digestible name of plausible inference (RESCHER 1976). The standard example goes back to antiquity. A small man is accused of having assaulted a bigger and stronger man. He defends himself by an appeal to common sense: why should he have been so silly to run such a risk (GAGARIN 1994:50)? The key to understanding plausibility is the adversarial principle that is formalised in court procedure. Here, each party is not only allowed to make its case as strong as possible, it is invited to do so. It is the task of the judge or the jury to find out which of these competing stories carries greater weight (WALTON 2001:151). In more formal terms, plausibility is a statement about likelihood, not about probability (HALPERN and MCALLESTER 1990). There is thus no well-defined space of potential outcomes, the probabilities of which add up to 1 . If there are two competing hypotheses, both may easily be equally plausible, and both may be more plausible than chance (WALTON 2001:151).

A third strategy of practical reasoning does even have a technical legal term in its name. It is called presumptive argument (WALTON 1996). "We have a presumptive reason for performing the action. This presumption can, however, be challenged and withdrawn. Subjecting our argument to appropriate challenges is how we hope to identify and consider the alternatives that require consideration, and determine the best choice for us, in the particular context [...] Whether this presumption stands or falls depends on satisfactory answers being given to the critical questions associated with the scheme" (ATKINSON, BENCH-CAPON et al. 2004:88). Actually the norm for good presumptive inference could be directly taken from a civil procedure textbook. Initially, a simple statement suffices. If the opponent objects, reasons for the statement must be given. 
"When the proponent puts forward a presumption, she does not have to back it up with proof, but she does have to give it up if the respondent can disprove it" (WALTON 2001:156).

Introducing the formal methods of the social sciences in court is thus much more than an invitation to change culture or taste. It requests that lawyers swap theoretical for practical reasoning. Since their task is not to advance our understanding of the world, but to rule in it, this would clearly be a mistake.

\section{Psychology of Judicial Decision Making}

The foregoing has explored the norm judicial decision making should follow. But do judges actually do so? The existing evidence does indeed point in this direction (discussed in Section a below). The underlying mental mechanisms can be characterised in two different ways. If one exclusively looks at deliberate reasoning, judicial decision making can be largely described by the psychological concept of holistic thinking (Section b). This should, however, be put into the broader context. Man possesses more than one decision mode, and judges do routinely have recourse to several of them simultaneously (Section c). Based on this, the effects of introducing formal methodology can be analysed (Section d).

\section{a) Phenomenology}

The key to judicial decision making is controlled intuition. Lawyers are permanently engaged in making sense of the available information (cf. TURNER 2001). They want to know whether the stories they are told by the parties are convincing. ${ }^{12}$ They see it as their task to construct a story of the events that comes as close to reality as is feasible, given the concrete circumstances of the legal decision being taken (PenNington and HAstie 1997); see also (BRUNER 1990; BRUNER 1997). They want to know whether a factual statement is credible and whether the concomitant doctrinal claim is plausible (cf. CHATER and OAKSFORD 2004:48). In all of this, they rely on common sense (FEIGENSON 2000:13 f., 44). In principle, they go about their judicial task the same way as they assess situations in everyday life (FEIGENSON 2000:110). They fill in the existing evidence with their general world knowledge (MEYER 1994; see also BRUNER 1973). It thus is natural for them to decide on an incomplete factual or conceptual basis (cf. CHATER and OAKSFORD 2004:44).

Judges routinely have recourse to soft concepts like exemplars (cf. BANDURA 1986:103; ANDERSON 2000:348), schemata (cf. BARTLETT 1932:206, 212 and passim; ANDERSON 2000:347 f.), scripts (cf. SCHANK and ABELSON 1977) and prototypes (FEIGENSON 2000:50; see also CANTOR, MisCHEL et al. 1982; LAKOFF 1987). They are not hostile to scientific knowledge. But they usually rely on the folk version (STEINER, BOWERS et al. 1999). Finally, for a judge, cognition and responsibility are closely intertwined (FEIGENSON 2000:88). Cognition is thus not a dis-

12 This does, of course, not exclude the alternative strategy, often used by the defendant, to repel the claimant's case point by point; more on this by FEIGENSON Legal Blame (2000) 97. 
tanced affair. It is undertaken in light of the final output and whether the judge feels able to take on responsibility for this. Eventually, judges want to feel right about their decision. They strive for congruence between cognition, emotions and the final decision (FEIGENSON 2000:69-86).

\section{b) Holistic Thinking}

There is a striking parallel between these stylised facts about judicial decision making and what has in psychology been called holistic thinking (NisBetT, Peng et al. 2001); see also (STICH 1990; STEIN 1996; CHATER and OAKSFORD 2001). It in general is more prevalent in Eastern than in Western societies (NISBETT, PENG et al. 2001), but it is also present in Western concepts of wisdom (BALTES and STAUDINGER 1993). Characteristic features of holistic thinking are: Experiential knowledge is more important than formal logic. The emphasis is on plausibility and on sense experience (NISBETT, PENG et al. 2001:301). Typicality matters more than rigour (SLOMAN 1993). If they are in conflict, holistic thinkers trust their beliefs more than logical validity (WILKINS 1928; EVANS, BARSTON et al. 1983). They are not disturbed by contradiction (GEERTZ 1983). They react to it by dialectically opposing competing views of the matter (NISBETT, PENG et al. 2001:301). They implicitly assume reality to be dynamic and changeable (FEIGENSON 2000:13). Causality is seen as a complex function of multiple factors operating on an object in a field (NisBetT, PENG et al. 2001:306).

Due to this, holistic thinkers are prepared to find as wrong today what seemed right yesterday (Nisbett, Peng et al. 2001:301). They do not pursue the one logical conclusion. They rather strive to detect degrees of covariation (NISBETT, PENG et al. 2001:306). Consequently, holistic thinkers are hungry for more supporting information. They are willing to heavily rely on their general world knowledge (OAKSFORD and CHATER 1998). However, a second, weaker argument does not increase, but decreases, their confidence in a statement (NISBETT, PENG et al. 2001:302). Holistic thinkers are sensitive to small variations in the environment (FEIGENSON 2000:14 f.). The rationale for deciding in favour of one perspective over another tend to be extremely subtle and elaborate, but at the same time incomplete and unsystematic (CHATER and OAKSFORD 2004:43).

The features listed indicate why attempts to formalise everyday reasoning have failed (CHATER and OAKSFORD 2004:44 f., 68). Such attempts have been undertaken in artificial intelligence, with the hope of later endowing computers with the ability of practical reasoning (PYLYSHYN 1987; PEARL 1988; FORD and PyLyShYN 1996). The main problem stems from the fact that holistic thinking engages knowledge that is inextricably entangled with further knowledge. It therefore is not possible to break it down into packets that could be processed by machines (MCDERMOTT 1987; see also FODOR 1983).

The general attitude towards thinking translates itself into what has been called folk-science (KeIL 2003). People understand the world around them to a much lesser degree than they think. They thus fall prey to an illusion of the depth of their knowledge (KEIL 2003:368). Instead, they rely on "intuitive theories" (KeIL 2003:368). People generally treat the world the same way that 
the ordinary user treats the hardware and the software of her computer. They know how to handle it for the kind of tasks they frequently face. From this knowledge base, they can draw useful analogies. But they typically know next to nothing about mechanism (KEIL 2003:370). Specifically, they underrate the amount of information they retrieve on line from the respective context (KEIL 2003:372). Moreover, folk-scientific knowledge is often implicit in the first place (KEIL 2003:370).

\section{c) Combination of Several Decision Modes}

Deliberate reasoning is not the only tool for decision making. Humans dispose of a plurality of decision modes (WEBER and LINDEMANN 2002). Others speak of a mental toolbox (PAYNE, BetTMAn et al. 1988; Gigerenzer and SELTEN 2001). It runs from the most primitive decision modes like reflexes (e.g. BLAU and BLAU 1955) over parsimonious, but context-rich heuristics (GIGERENZER, TODD et al. 1999) to fairly complex, task-specific skills that may be triggered by just one cue (ANDERSON 2000:chapter 9).

The plurality of decision modes allows humans to capitalise on different mental and external resources. If appropriate, they can use external devices for the provision of information, for memory, for execution and even for the actual decision making. Mentally, serial processing according to the laws of logic is not the only ability. Along with it goes intuition (STRACK and DEUTSCH 2002). It may best be explained by the capacity of parallel processing, which is largely exercized at the subsymbolic level (LOVETT and ANDERSON 2005); see also (GLIMCHER 2003).

Judges do not decide by reflex. Hopefully, judicial decision making by a rigorously simplified heuristic is a rare event (but see DHAMI and AYTON 2001). This is, however, not to say that judicial decision making is nothing but deliberate reasoning. It is more appropriate to view judicial decision making as a fairly elaborate skill. A parallel extensively studied by psychologists is playing chess. Although the confines of the board and the permissible moves are all precisely defined, sheer complexity makes it impossible to just calculate. ${ }^{13}$ Instead, experienced chess players have stored a rich array of typical patterns in memory. Deciding between these patterns is usually more a matter of feeling than of knowing. This is not to say that chess players do not reason. But their reasoning is more local in character. It may be characterised as the finish to a decision-making process, which musters other mental resources as well (GROOT 1965).

\section{d) Impact of Formal Social Science on Judicial Decision Making}

In Eastern societies, decontextualising practices are disapproved of (NISBETT, PENG et al. 2001:301). Formal rationality appears alien to those accustomed to everyday reasoning (CHATER and OAKSFORD 2004:46). Since judicial decision making has been demonstrated to be in the neighbourhood of contextual, everyday reasoning, the prevalent reluctance of lawyers to rely on 
the rigorous methods of the social sciences should be less of a surprise. The psychology of judicial decision making does not lend itself to this kind of reasoning.

Moreover, by incorporating elements of rigorous methodology, judges might impair the proper functioning of the predominant decision mode. The following line of argument supports this concern:

Social organisation directs attention to some aspects of the field at the expense of others. What is attended to influences metaphysics, that is, beliefs about the nature of the world and about causality. Metaphysics guides tacit epistemology, that is, beliefs about what it is important to know and how knowledge can be obtained. Epistemology dictates the development and application of some cognitive processes at the expense of others. Social organisation and social practices can directly affect the plausibility of metaphysical assumptions, such as whether causality should be regarded as residing in the field versus the object. Social organisation and social practices can influence directly the development and use of cognitive processes such as dialectical versus logical ones (NisBetT, PENG et al. 2001:292).

Specifically, islands of rigorous methodology might siphon away attention and resources that are no longer employed to consider information that cannot be presented the same way. Even with the most advanced methodological skills and the best of all intentions, complexity would quickly be overwhelming otherwise (CHATER and OAKSFORD 2001:211). Moreover, judges might be discouraged from apparently vague argument where some of the competing concerns are presented in splendid clarity. A further explanation resides in the skill character of judicial decision making. Skills are not easily unpacked. Integrating new elements into an existing skill is possible, but laborious. Until this is achieved, overall decision quality is likely to decrease. Finally, skills do not only save effort and improve decision quality. They also endow the decision maker with the subjective feeling of competence. Since they lack the necessary training, judges might easily feel insecure when applying the social science methods. This might lead to inappropriate hesitation, or to nervous blunders.

\section{Doctrinal Impediments}

If they are to be relevant for judicial decision making, the rigorous methods from the social sciences must find their doctrinal pigeonholes. This is not categorically excluded. The practically most important doctrinal opening is teleological construction. Due to the hermeneutical character of doctrine, teleological construction is not only relevant for the normative part of decision making, but also for the descriptive part of it. The telos then determines which elements of the case are relevant for the decision.

In the civil law countries, the courts are not even formally bound by legislative intent. Rather, the text of the statute is the interface between the process of making new law in Parliament and the process of applying new law in the courts. It is the task of the courts to interpret this text. What 
the legislator had in mind when drafting it is not irrelevant. But the travaux préparatoires are only one canon. If it points in one direction, the courts may nonetheless rely on one of the other canons to decide otherwise. Most often, it is telos that prevails over legislative intent. In the common law countries, the formal respect for Parliament is more pronounced. But in these countries, the judges may engage in creatively interpreting legislative intent to get around this.

However, the need for a doctrinal opening creates a problem of double strictures. For a judge, the primary stricture is in the text of the applicable provisions and of the interpretive tradition attached to it. Quite frequently, a good deal of creativity is required to bring the facts of the conflict of life under a pertinent provision. It thus is not enough for a judge to find a good solution to the underlying conflict. This solution must go through the conduit of a host of doctrinal restrictions. It is no easier to design a rigorous model that captures the essence of the conflict of life. It is equally demanding to design an experiment that makes it possible to uncover an essential feature of the case according to statistical standards.

If formal methods are introduced in court, both these strictures must be met simultaneously. This is bound to be challenging. Moreover, the more credit given to social science methodology, the more judges might be attracted to doctrinal carelessness. This would impair the rationalising effect that doctrine has for law. Judges might be tempted to disregard normatively relevant features of the case that are not captured by the social science methods applied in order to avoid double strictures. One may also put the conflict between doctrine and social sciences methods this way: both must stylise facts, both must construct reality, both must partly decontextualise, but normally not the same way.

\section{Procedural Impediments}

Likewise, the formal rules for judicial procedure may make it difficult to incorporate social science methods (cf. EIDENMÜLLER 1995). The most obvious impediment is in the rules for access to facts. In principle, the court is not free about how to inform itself about the case or the underlying social conflict. The court must wait for the parties to make statements. If the parties agree on a fact, the court may, in principle, not question the veracity of this statement. If a statement is disputed, in principle, the only way for the court to learn more about reality is through formal proof.

Formal proof in court is ill-suited to generate the kind of facts a social scientist would want to know. It is true that proof may be extended to facts transcending the case. For instance, the facts of a related conflict may be investigated if that is the only way to assess the veracity of the disputed statement concerning the case itself. But in statistical analysis, many facts are only needed in order to fulfil methodological needs. It is hard to imagine that a court should oblige hundreds of outsiders to make data available in the interest of getting at significance. Likewise, procedural rules would not possibly allow strict methodologically controlled experiments with outsiders 
against their will. Generating new generic knowledge is not a problem court procedure is made for. However, this is what the social sciences focus on.

Admittedly, the court is allowed to exploit information that is publicly available. The court is therefore, in principle, not hindered from relying on statistics that have been produced for different purposes. However, there are two normative problems with this. First and foremost, in statistics no less than in other means of investigation, the question drives the result. If the data set has been collected for a different purpose, it may well be biased in a way one of the parties may not find acceptable for deciding the case. This holds even more for statistical tests that he been undertaken in a different context. There is therefore a true risk that the court will be misled by a finding that has not been generated under its control.

Moreover, if exploiting foreign statistics becomes a regular court practice, this will have repercussions on the generation of the information in its context of origin. A practical case has come up in German broadcasting regulation. German law has media-specific anti-concentration rules. These rules are cumulatively applied with antitrust. Whether a merger is allowed depends on the number of viewers reached. The broadcasting authorities did not want to compile their own statistics. Rather, they intended to rely on the statistics produced by the broadcasters themselves in the interest of the advertising industry. The company doing this for the broadcasters fought fiercely against this move. They were afraid that, in the future, they would no longer be able to smoothly adapt their methods of data gathering to the needs of the advertising industry (more from ENGEL 1995).

Rigorous models present the law with a related problem. They are best at the exact analysis of relatively complex relations and at giving precise quantitative tipping points. The classic illustration is models in economics that define equilibrium as the point where marginal demand equals marginal supply. Usually, court procedure is not able to produce information that fine grained. There are two reasons for this. Procedural law takes it for granted that the parties will want to shift the balance in their own favour. Procedural law is therefore full of safeguards against strategic behaviour in the process of information gathering. Moreover, courts are able to generate proof against the will of those who hold the necessary information. Since sovereign powers are exercised, the generation of information must be limited. This follows from rule of law.

The distinction between objectivity and truth outlined above translates itself into procedure. The scientific response to doubt is methodological standards. From the principle of falsification, it follows that doubt is never fully removed. All scientific results are provisional. The legal response to doubt is proof and sovereign decision making. By these techniques, all legal results are final. Proof responds to doubt about the facts. Whether the proofs offered have been conclusive is settled by decision. Due to the principle of conviction intime, this decision is openly subjective (for references, see again DEMOUGIN and Fluet 2005). It engages the judge or the jury as individuals holding an office. If a proof has been inconclusive, all uncertainty is artificially removed by the rules about the burden of proof. Although nobody has ever tried to prove the opposite statement, the judgment is based on the absence of the disputed fact. In criminal procedure, the 
effect is most pronounced. The defendant may well have committed the crime. But the burden of proof is entirely on the attorney general. ${ }^{14}$ If only one fact necessary for conviction is not able to be proved, the defendant is acquitted.

By the rules on proof, the law thus artificially creates certainty. This becomes more difficult if legal decisions are partly based on statistics. The judge could not possibly state in the reasons that he, as a prudent man, has not been convinced by the 5 percent significance level. Effectively, if it opens itself up to statistical proof, the law must go back to the old practice of formal rules of proof (Schulz 2005). During the Enlightenment, they were removed. The most infamous is the medieval rule that one needed two respectable witnesses or a plea of guilty. The rule directly led to torture.

By a similar technique, the law draws a strict line between provisional and final decisions. Usually, there is room for appeal against the original authoritative decision. But the right of appeal is limited in time, often also in substance. For instance, the final stage in court hierarchy may usually only be approached with claims of law, not with claims of fact. Once the options for appeal have been exhausted, or appeal is no longer admissible, the decision becomes binding. For the law, the underlying social problem no longer matters. The decision is enforced, even if a scientist could prove that it is materially wrong. Of course, patently wrong authoritative decisions are always hard to tolerate. But due to the openly subjective element in judicial decision making, the tension is less pronounced than in a decision based on scientific argument. There are two reasons for this. It is easier to show that and why the binding decision is wrong. Since science permanently strives for progress, it is also much more likely that the poor quality of the decision will indeed be uncovered.

Finally, introducing scientific rigour would be likely to change the interaction in court in normatively unwanted ways. This is most obvious if a substantial portion of the decision is in the hands of a jury. Juries are not likely to properly handle, and to rightly assess, statistical evidence or formal models. And they have indeed been demonstrated to err profoundly in these respects (KOEHLER 2006). Training jurors, or making their selection more demanding, ${ }^{15}$ is not possibly a way out. If it is transformed into a bench of experts, the jury betrays its very purpose. Juries have been introduced precisely in order to strengthen the non-expert influence on judicial decision making. Also, a highly select jury could no longer provide the court system with additional legitimacy. ${ }^{16}$

In similar ways, rigorous social science methodology would affect the position of the parties. If winning a case hinges upon swiftly handling this methodology, the parties will quickly learn. Specifically, attorneys would specialise in this. Maybe, trained social scientists would become

14 Criminal lawyers normally use different language for this. They speak of the presumption of innocence.

15 This is JONATHAN KOEHLER's advice.

16 This is not to say that jury decision making could not be reduced or abolished. Comparative law demonstrates that different legal orders think quite differently about the desirability of juries. But the ability of the court system to handle social science methodology would probably not be the most important concern in such a shift. 
members of law firms. However, this would make access to court a more elitist affair. Those who could not afford the expensive law firm would be even more likely to lose their case than they are already. Moreover, for most parties, what happens in court would be even more inaccessible than now. All they could do is put their fate in hands of those specialists who know to handle the methodological requirements. Most importantly, however, the interaction between the parties and the court would have to change. Since judgment is currently on line, in principle new facts and new argument may be brought in until the last moment. Since rigorous methodology has strictly controlled openings for judgment, the strategic interaction must concentrate on these openings. Practically speaking, most of the action in court would have to be upfront. Chances in court would largely hinge upon the ability of the attorney to rightly anticipate the effect of apparently innocuous ex ante choices on outcome.

\section{Autonomy of the Legal System}

Often, one and the same observation can be made in different conceptual languages. This is not a waste of energy. Through different lenses, different aspects of the phenomenon become visible. Since each additional language is taken from a different background, different analogies are triggered. Above, the role of formal social science in the law has been regarded from an individualistic vantage point. It has predominantly been the perspective of the judge, occasionally also the perspective of other actors in the judicial procedure. The same question may also be asked from a systemic perspective. Will the integration of formal social science hamper the ability of the legal system to fulfil the social function entrusted to it?

If one asks this question in the abstract, it is natural to rely on systems theory for the response. It is clear-cut. In NiKLAS LUHMANN's theory, science and law are two different subsystems (LUHMANN 1990; LUHMANN 1993). Like all subsystems, they are distinguished by their use of a unique code. Science is organised along the distinction between true and false. The law is organised along the distinction between legal and illegal. The characteristic feature of a subsystem is autopoiesis. The subsystem decides autonomously whether an input from a different subsystem is relevant, or just noise. In principle, for the receiving subsystem, neither intention nor clout in the sending subsystem matter. Applied to the interface between social science and law: in principle, law might rightly ignore a social scientist who claims she is able to better understand the legal conflict. If social scientists frown at the quality of legal argument, lawyers could well respond that this is none of their business. However, the point should not be overstated. Systems theory does not claim that the law must ignore all statements by social scientists. It only insists that the norm for choosing between openness and closure must exclusively be a legal one. Specifically, if this is necessary for the viability of the legal system, it is not only entitled to disregard social science methodology. This is even what it ought to do.

It may indeed be argued that taking the social science methodology on board interrupt the smooth functioning of the legal system. Tongue in cheek, lawyers sometimes say: there is no topic that is beyond me. Not so rarely, this is just hubris, if not mere ignorance. Nonetheless, 
there is a kernel of truth to it. The legal system is permanently faced with novel situations and conflicts. It could not possibly wait to regulate them until scientists think they have sufficiently understood them. The individual judge is constitutionally obliged to decide whatever case is brought before her, as long as jurisdictional demarcations are respected. She cannot call in another judge on grounds of insufficient skill or understanding. The constitutional rule has been introduced because there are so many degrees of freedom in legal decision making. Therefore, it should be determined who is going to decide even before the case has occured. At the margin, the court system responds to the ensuing problem of subject-matter competence by specialisation. For instance, in many German civil courts, there is a special bench for disputes over medical malpractice. However, the methodological demands in a field of law may not be pushed beyond a level that ordinary judges are able to capture (HOFFMANN-RIEM 2001:15).

Related to this are resources. Scientific methods assume potentially unlimited resources. If this one researcher lacks the funds or skills, she should select another research topic. Those better prepared should take the question up. If it is not possible to understand the question in a methodologically acceptable way, it must wait. Not so rarely, entire disciplines choose a lengthy detour if the true question seems beyond methodological reach. ${ }^{17}$ Contrary to this, the resources available to decide one given case are bound to be limited. This not only concerns money and education, but above all time. The legal system at large can muster many more resources. Through inputs from individual cases, gradually a body of knowledge about how to handle a new class of disputes can accumulate. But this too must happen within a reasonable time framework.

In comparison to science, the legal benchmark is much more flexible. Of course, there are methodologically unacceptable statements in the law. But the threshold is a fairly low one. Once it is overstepped, subtle rules of thumb are applied. If a statement is acquired wisdom in the legal community, it need only be referred to. If one introduces a piece of new knowledge into legal discourse, it is enough to show its plausibility. If this piece is disputed, the knowledge must be corroborated. This may be done by further argument, or by reference to authorities. Scientists do frequently play that role in legal procedure. The highest standard is to be met if a lawyer challenges acquired wisdom. Even the lower courts would often refrain from such statements, and rather have the losing party appeal. It would not be easy for the legal system to maintain this flexibility if formal methodology from the social sciences were introduced. For it is the very purpose of rigorous methodology to provide science with a strict benchmark.

In ideal types, the legal method is bottom up, not top down. Law is best at gradually building an understanding of a more abstract issue by deciding a host of cases, each in its full context of origin. This, for instance, explains why the courts often try to decide "as close to the facts as possible". By this, they mean that sweeping statements should be withheld where there is poten-

17 A good example is behaviourism. In the early 20th century, it was very difficult to make rigorous statements about the brain in action. SKINNER therefore urged psychology to leave its very object of study aside. It should no longer speculate about what happens within the brain, and it should focus on observable inputoutput relations instead (SKINNER Behaviour of Organisms 1938). The position held sway over the discipline until the cognitive revolution some 20 years later (СНOMSKY in Language 1959). 
tially insufficient understanding. Of course, scientific texts explicitly state the conditions under which the results hold. But scientific investigation is undertaken in the interest of uncovering general statements. Routinely, scientific papers start by a general hypothesis derived from an explicit theoretical framework. In this sense, scientific investigation is top down. If it opened itself up to social science methodology, law would have to shift to this approach.

On an even more pragmatic level, social science methodology would be driving a wedge between the lower and the higher courts. Due to a lighter caseload and more resources, eventually the higher courts might be able to live up to these standards. However, the lower courts could not possibly follow suit. In civil affairs, a single judge in a German Court of First Instance (Amtsgericht) has a docket of more than a thousand cases per year. Likewise, the strict methodological standards of the social sciences would drive a wedge between legal practice and legal academia. For academics, it would of course be possible to adopt the standards of the neighbouring fields. However, legal practice could no longer directly rely on academic work in day-to-day decision making.

\section{Fuzzy Goal Function of the Law}

As demonstrated, the difference between an explanation and a decision task is not a small one. Yet this is only part of the difference between the social sciences and judicial practice. For the goal function of the law is fuzzy on purpose (ENGEL 2001a). There is no single measurement rod for a good legal decision. Rather, the law specialises in balancing concerns that are impossible to express in one and the same normative currency. The law thus permanently trades better performance in one dimension for deterioration in another. Multidimensionality is a standard situation for law. Law is the quintessential "clumsy institution" (SHAPIRO 1988). Admittedly, modellers have not ignored multidimensionality (e.g. HELLWIG 2004), and lawyers have tried to rationalise balancing (ALEXY 2003). But attempts at bridging the gap start from fairly remote points. Currently, we seem far removed from a true formalisation of all the considerations that legitimately enter legal decision making. Introducing formal social sciences into law entails a twofold risk. Law might reduce the decision programme such that it becomes methodologically tractable. The selection might be prejudiced against those concerns that are harder to model or quantify.

It is beyond the scope of this paper to draw a colourful picture of the richness in the legal goal function. Suffice it to highlight the most salient features. The law is always normative, but there is no agreed upon basic value. The law thus has to live up to fundamental normative relativity (ENGEL 2001b), and to the plurality of social constructions that are behind normative convictions (THOMPSON, ELLIS et al. 1990).

Court cases are not carefully randomised experiments. They originate in value-laden, emotional conflict (FARNSWORTH 2000). Conflict resolution is therefore an important element of the judicial task, and its imperatives may be orthogonal to finding a substantially good decision (ENGEL 2003). Even if the parties are more tempered, they care about procedural utility and procedural 
fairness, not only about the final outcome (TYLER 1990; FREY and STUTZER 2001). If there is resistance, court decisions may eventually be enforced by sovereign intervention. In practice, this is, however, a rare event. Usually the losing party abides by the decision without further ado. This beneficial effect, however, rests upon the ability of the court to make the loser understand why he lost. The representation of court decisions must thus aim at what the parties are able to understand (ENGEL 2004a). Ideally, the formal application of the law should also be an occasion to actualise social norms (POSNER 2000a), to shape mental models (JOHNSON-LAIRD 1989; cf. MANTZAVINOS 2001) and to create templates for the normative expectations inherent in an abstract rule that travel beyond the parties of the case (ENGEL 2004c). For all these reasons, the discursive element of judicial procedure is crucial. It must respect the mindsets of the law's addressees. Specifically, making the precarious character of all judgment explicit, as the social sciences do, may be counter-productive on these grounds.

The courts exercise sovereign powers. In most jurisdictions, judges are, however, not directly elected. Therefore, judicial authority may not be taken for granted. If rigorous social science methodology features prominently in judicial decision making, generating legitimacy may become more difficult for the court system (cf.EIDENMÜLLER 1995:437 f.). Neither the legislator nor public opinion will be able to directly assess judicial output. Due to methodological standards, decision making becomes more arcane. However, those acquainted with social science methodology are able to criticise the courts in a much more pungent way than previously. There is a serious risk that the courts just will make methodological mistakes, or that their products will have poor quality. This may happen inadvertently, or in response to another element from the fuzzy goal function of the law.

\section{Benefits from Integrating Rigorous Descriptive Social Science into Law}

In court practice, attorneys often follow a simple heuristic of tallying. If the opponent's attorney has written a brief of 100 pages, they respond with 110. They are afraid a short response might convey the impression that their reasons carry less weight. This paper ignores the legal rule of thumb. It uses fewer words to argue for the integration of formal social science into law than to argue against it. This is not to say that the case for rigorous methodology is doomed to failure. But this case has often been made already. Actually it is behind the entire programme of formal law and economics (see only Posner 2003; COOTER and ULEn 2004) and of the statistical analysis of legal issues (e.g. KLERMAN and MAHONEY 2004). Even worse, I have already written on the topic, and do not want to repeat myself (ENGEL 1998b). Suffice it therefore to briefly recall the key arguments, and to put some of the arguments against the integration of formal social science in perspective.

The prime reason for openness is straightforward. Precision is no value as such in legal decision making. But materially wrong decisions are not acceptable. Rigorous methodology provides the law with a better understanding of the issue at hand. It prevents the courts from falling prey to 
their untrained intuitions, or even from being strategically misled by one of the parties. Formal models allow us to significantly push the frontier of our understanding of complex causal relationships. Both models and statistics permit us to analyse quantity, not only quality. Logical mistakes (EvANS, NEWSTEAD et al. 1993) and inconsistency (CHATER and OAKSFORD 2004:49; ENGEL 2004b) are easier to detect. Relying on rigorous methodology, critics have a benchmark for assessing the technical quality of practical legal reasoning (CHATER and OAKSFORD 2004:49; HARMAN 2004). Although technical quality is rightly not the prime concern, knowing the distance is still relevant.

In many fields of law, the legislator is no longer content with codifying common sense. She intends to regulate, if not to proactively change, complex phenomena like competition, environmental protection or demography. In such contexts, understanding the local conflict between the parties before the judge is often insufficient. In order to execute the legislator's will (or to reshape it, for that matter), one needs a much broader understanding of the social problem. This is not likely to be generated by mere introspection, or by the everyday experience the judge shares with all other members of society. Nobody would accept the judge convicting a doctor on grounds of her better knowledge of medicine. No less expertise is necessary to understand complex social phenomena.

The law is strongest where it has time to acquire experience. By gradually working itself through a line of colourful cases, the legal system gains an ever better understanding of the issue. Unfortunately, many issues do not provide the judiciary with such a comfortable situation. It is forced to take far-reaching decisions, based on little, if any, experience. In such situations, relying on the skills of the social sciences allows us to base legal decisions on much better predictions.

Even if practical reasoning is in principle adequate for legal decision making, it may err in predictable ways. Even taking the different task and the characteristic definition of the situation into account, the legal order may want to avoid some of these mistakes. To the extent that this is the case, formal methodology helps detect them. For instance, lawyers have been demonstrated to fall prey to framing (KeLmAn, RotTEnstreich et al. 2000; MCCAFFERY, KAHNEMAN et al. 2000; RACHLINSKI 2000:96-99; GUTHRIE, RACHLINSKI et al. 2001:794-799), anchoring (HINSZ and INDAHL 1995; RACHLINSKI 2000:96-99; ENGLICH and MuSSWEILER 2001; GUTHRIE, RACHLINSKI et al. 2001:787-794) and the fundamental attribution error (FEIGENSON 2000:15).

Finally, formal methods may help prevent lawyers from abusing findings from neighbouring disciplines. Such abuse is frequent in practice. Usually, when results from other disciplines enter law, they are stripped of all caveats. The legal audience is told nothing about assumptions, robustness checks, probability models, confidence intervals or significance levels. Typically, the results are presented as if there were no dispute in the other discipline. The findings are rhetorically put into contexts for which they do not hold. Ultimately, such use may be acceptable if it helps the law to do a better job in decision making. But there is considerable danger that legal decisions are indeed materially misled that way. 


\section{The Art of Integrating Formal Social Science into Law}

How can the law reap the benefits of formal social science without putting its core functions at risk? Which are the necessary filters (HOFFMANN-RIEM 2001:16)? How can the distance be bridged (HOFFMANN-RIEM 2004:60-62)? There is no one-size-fits-all answer to these questions. The integration of rigorous methodology into law is an art, not a science. Given the many legitimate concerns listed above, every new case, every new topic and every new academic paper must find the individually best way to carry off the integration. The following generalisations are no more than indicators. Whether they fit, or whether new and better ways are found, must be left to the inventiveness of those who are actually doing it.

If lawyers are overwhelmed by complexity, their standard response consists in replacing substantive by procedural governance. If an administrative agency is granted discretion, the judicial control of decision-making procedure in the agency becomes all the more stringent. It has been suggested that a similar mechanism be used to handle the interface between formal social science and the law. Rigorous methodology should be admissible in court only if a statute permits the courts to rely on it (EIDENMÜLLER 1995). This can hardly be convincing. One may already question whether the legislator understands formal social science any better than the courts. At any rate, the legislator is not likely to adequately administer the interface between science and judicial decision making. The responsibility for deciding about the limits of integration must be with those who are actually struggling with the strictures of applying law to fact. Moreover, practising lawyers would normally be hard pressed to find any explicit statement of the legislator. Usually, reading between the lines of legislative materials is the most they could hope for. If the suggestion were accepted in practice, it would simply make for more red tape. Before actually using an argument based on the methodology of a neighbouring discipline, the judge would have to write down a few justifying lines. There would always be a pertinent statement in the legislative materials if needed.

Not all legal topics are equal. Using a rational choice model to understand the effects of regulated access by competitors to telecommunications networks does not seem far-fetched (ENGEL and KNIEPS 1998; ENGEL 2002c). Here too, the legal argument cannot be reduced to this. For instance, rule of law and the limits of justiciability play an important role. But rational choice modelling is much harder to digest if applied to, say, criminal sanctions on abortion. The closer the regulatory concern comes to an issue that naturally lends itself to a defined conceptual framework of a social science, the more the law has to gain from opening itself up to the methodological standards of this discipline. Consequently, the relative weight of the standard legal counterarguments decreases.

The two examples illustrate a further natural distinction. In disputes over network access, an actual or potential competitor desires access to the network of the incumbent. The competitor may in many respects be weaker than the incumbent. But competitors are firms, and enforcing access is a central element of their business plan. If the law allows for a good deal of methodological sophistication in deciding about the complaint, this is not likely to generate a problem of 
fairness. Both parties will be represented by the best lawyers they can get. If this is appropriate, these lawyers may bring in economists as experts. None of this would work in an abortion case.

Another option consists in exploiting the distinction between the generation and the representation of court decisions. There are, of course, substantial and necessary links between both (ENGEL 2004a). But the reasons provided for a judgment are not meant to be a description of the way the court has found it. Rather the reasons summarise those facts and those arguments that eventually turned out to be decisive. Also, the reasons legitimately speak with several voices. They are meant to convince the losing party that the decision could not have been otherwise. The parties are to learn what the judgment means for their future interaction. Higher courts are to be able to control the decision-making body. Finally, via the reasons, the court contributes to the professional discourse of lawyers, and to the evolution of law (ENGEL 2001a). Against this backdrop, two options present themselves. The court might well rely on rigorous methods from the social sciences to generate its decisions, but it might write down a different, more accessible justification. Moreover, if the court wants to keep some of the rigour for the written reasons, it might write another part aiming at less sophisticated readers.

The most important distinction, however, is the one between the court system and legal academia. In principle, legal academics might entirely ignore the concerns listed above, and exclusively contribute to the scientific discourse in the field from which the rigorous methodology is taken. Actually, this is what many law and economics scholars have chosen to do. Doing so changes the character of the law as an academic discipline. It cuts the ties to jurisprudence. In order to mark the difference, one might speak of legal science, or of legal studies. ${ }^{18}$

There is nothing to be said against legal science in the sense just described. It is as useful as studying political institutions and the political process with the same conceptual apparatus. But those academics pay a price. They deliberately stop being actors within the legal system, and become mere observers. The judicial system will normally pay little attention to what they are doing, and for good reason. It will be unpredictable whether doctrine will pick up elements of this scientific discourse. If it does, what arrives in the legal system will exclusively be driven by its own dynamics.

The artistic component involved in integrating social science methodology into the law begins when an academic wants to serve the community of practising lawyers, but also to live up to methodological standards. Such exercises are necessary, because otherwise no true "division of cognitive labour" (KEIL 2003:368) occurs. Legal academia is uniquely situated to do precisely this. It may have access to both communities. From legal practice, and from those academics even closer to practice, it may learn about doctrinal evolution and the underlying real-life experiences. From the neighbouring discipline, such academics may not only learn methodological tools, but also how to apply them swiftly. Such academics may thus best be understood as interface actors (cf. HUTTER 1989). It is their self-chosen task to creatively link both disciplines. 
In practical terms, these interface actors must gradually accumulate a body of experience regarding how to productively integrate rigorous methodology. The integration is easiest if there is already a doctrinal controversy. Practising lawyers are likely to pick the results up if the underlying conflict is rigorously modelled, or if an empirical hypothesis is rigorously tested. However, just writing down a model in mathematical language, or presenting a regression plot, will not do. If they are to have an impact on legal practice, such papers need a substantial introduction, telling practising lawyers how the model is derived from doctrine. Similarly, the results must be translated into a language spoken by legal practice. ${ }^{19}$ A second option starts from a policy problem handled by law. Due to the policy orientation, the academic will not be able to just use one scientific concept. Consequently, the result will usually not be methodologically clean. But such a study may at least integrate more rigorous parts where this helps understand a crucial element of the issue. ${ }^{20} \mathrm{~A}$ third option starts from a scientific finding or tool and explores its importance for practical law. Such a paper may easily start rigorously, but it will have to incorporate richer content in the explorative part. ${ }^{21}$

These examples demonstrate: the concerns about integrating rigorous social science into law are to be taken seriously. But there is no reason to throw out the baby with the bathwater. On the contrary: it is the proper role of legal academia to serve as an interface actor between the social sciences and judicial practice. This is a challenging, but a manageable task.

19 Although I am not using mathematics, the following paper is written with this intention, ENGEL in Die Verwaltung (1998a).

20 The best illustration of this approach in my work is ENGEL Abfallrecht (2002a) .

21 For this approach, the following paper may serve as an illustration, ENGEL in Engel, Halfmann and Schulte (2002b). 


\section{References}

Ackerman, Frank and Lisa Heinzerling (2002). "Pricing the Priceless. Cost-Benefit Analysis of Environmental Protection." University of Pennsylvania Law Review 150: 1553-1584.

Adler, Mathew D. and Eric A. Posner (2000). "Cost-Benefit Analysis. Legal, Economic and Philosophical Perspectives. Introduction." Journal of Legal Studies 29: 837-843.

Adler, Matthew D. and ERIC A. Posner (1999). "Rethinking Cost-Benefit Analysis." Yale Law Journal 109: 165-247.

Alexy, RoBert (2003). Die Gewichtsformel. Gedächtnisschrift für Jürgen Sonnenschein. Joachim Jickeli, Peter Kreutz and Dieter Reuter. Berlin: 771-792.

Anderson, John R. (2000). Learning and Memory. An Integrated Approach. New York, Wiley.

Aristotle and Frederic G. Kenyon (2003). Aristotle on the Constitution of Athens. Union, NJ, Lawbook Exchange.

Atkinson, Katie, Trevor Bench-Capon, et al. (2004). Justifying Practical Reasoning. Proceedings of the Fourth Workshop on Computational Models of Natural Argument. Floriana Grasso, Chris Reed and Giuseppe Carenini. Valencia: 87-90.

Axer, Peter (2000). Normsetzung der Exekutive in der Sozialversicherung: ein Beitrag zu den Voraussetzungen und Grenzen untergesetzlicher Normsetzung im Staat des Grundgesetzes. Tübingen, Mohr Siebeck.

Baltes, Paul B. and Ursula M. Staudinger (1993). "The Search for a Psychology of Wisdom." Current Directions in Psychological Science 2: 75-80.

Bandura, Albert (1986). Social Foundations of Thought and Action. A Social Cognitive Theory. Englewood Cliffs, N.J., Prentice-Hall.

Bartlett, Frederic C. (1932). Remembering. A Study in Experimental and Social Psychology. Cambridge, [Eng.], The University Press.

Baumol, William J. (1965). Welfare Economics and the Theory of the State. London, London School of Economics and Political Science; G. Bell.

Becker, Gary Stanley (1976). The Economic Approach to Human Behavior. Chicago, University of Chicago Press.

Berger, Peter L. and Thomas Luckmann (1967). The Social Construction of Reality. A Treatise in the Sociology of Knowledge. Garden City, N.Y., Doubleday. 
Blau, Theodore H. and Lili R. Blau (1955). "The Sucking Reflex. The Effects of Long Feeding Vs. Short Feeding on the Behavior of a Human Infant." Journal of Abnormal and Social Psychology 51: 123-125.

BÖGE, Ulf (2004). "Der "more economic approach" und die deutsche Wettbewerbspolitik." Wirtschaft und Wettbewerb 54: 726-733.

Bruner, Jerome (1997). "A Narrative Model of Self-Construction." Annals of the New York Academy of Sciences 818: 145-161.

Bruner, Jerome S. (1973). Beyond the Information Given. Studies in the Psychology of Knowing. New York, Norton.

Bruner, Jerome S. (1990). Acts of Meaning. Cambridge, Mass., Harvard University Press.

Brunswik, Egon, Kenneth R. HAmmond, et al. (2001). The Essential Brunswik. Beginnings, Explications, Applications. Oxford ; New York, Oxford University Press.

Cantor, Nancy, Walter Mischel, et al. (1982). "A Prototype Analysis of Psychological Situations." Cognitive Psychology 14: 45-77.

ChAter, Nick and Mike OAKSFord (2001). "Human Rationality and the Psychology of Reasoning. Where Do we Go from here?" British Journal of Psychology 92: 193-216.

ChATER, NiCK and Mike OAKSFORD (2004). Rationality, Rational Analysis, and Human Reasoning. Psychology of Reasoning. Theoretical and Historical Perspectives. Ken Manktelow and Man Cheung Chung. Hove, Psychology Press: 43-74.

CHOMsky, NoAm (1959). "A Review of B.F. Skinner's Verbal Behavior." Language 35: 26-58.

Coleman, James Samuel (1990). Foundations of Social Theory. Cambridge, Mass., Belknap Press of Harvard University Press.

Cooter, Robert and Thomas Ulen (2004). Law and Economics. Boston, Addison Wesley Longman.

Cowan, Robin, Paul A. David, et al. (2000). "The Explicit Economics of Knowledge Codification and Tacitness." Industrial and Corporate Change 9: 211-253.

DASTON, LORRAINE (1999). Objectivity versus Truth. Wissenschaft als kulturelle Praxis, 17501900. Hans Erich Bödeker, Peter Hanns Reill and Jürgen Schlumbohm. Göttingen, Vandenhoeck \& Rupprecht: 17-32.

Demougin, Dominique and Claude Fluet (2005). "Deterrence vs. Judicial Error. A Comparative View of Standards of Proof." Journal of Institutional and Theoretical Economics 161: 193-206. 
Dhami, Mandeep K. and Peter Ayton (2001). "Bailing and Jailing the Fast and Frugal Way." Journal of Behavioral Decision Making 14: 141-168.

Dilthey, WiLhelm (1923). Die Entstehung der Hermeneutik. Gesammelte Schriften V. Wilhelm Dilthey. Leipzig, Teubner: 317-331.

Driesen, DAvid M. (2000). Getting Our Priorities Straight. One Strand of the Regulatory Reform Debate. http://papers.ssrn.com/paper.taf?/abstract_id=245638.

DwORKIn, Ronald M. (1977). No Right Answer? Law, Morality and Society. Essays in Honour of Herbert Lionel Adolphus Hart. Peter M.S. Hacker and Joseph Raz. Oxford, Clarendon: 58-84.

EIDENMÜLlER, HoRst (1995). Effizienz als Rechtsprinzip. Möglichkeiten und Grenzen der ökonomischen Analyse des Rechts. Tübingen, Mohr.

ENGEL, CHRISTOPH (1995). "Die Messung der Fernsehnutzung als Voraussetzung eines Marktanteilsmodells zur Kontrolle der Medienkonzentration." Zeitschrift für Urheber- und Medienrecht: 653-666.

Engel, Christoph (1998a). "Die privatnützige Enteignung als Steuerungsinstrument." Die Verwaltung 31: 543-558.

ENGEL, CHRISTOPH (1998b). Rechtswissenschaft als angewandte Sozialwissenschaft. Die Aufgabe der Rechtswissenschaft nach der Öffnung der Rechtsordnung für sozialwissenschaftliche Theorie. Methodische Zugänge zu einem Recht der Gemeinschaftsgüter. Christoph Engel. Baden-Baden, Nomos: 11-40.

ENGEL, ChristoPH (2001a). Die Grammatik des Rechts. Instrumente des Umweltschutzes im Wirkungsverbund. Hans-Werner Rengeling. Baden-Baden, Nomos: 17-49.

ENGEL, CHRISTOPH (2001b). "Offene Gemeinwohldefinitionen." Rechtstheorie 32: 23-52.

Engel, CHRISTOPH (2002a). Abfallrecht und Abfallpolitik. Baden-Baden, Nomos.

ENGEL, CHRISTOPH (2002b). Rechtliche Entscheidungen unter Unsicherheit. Wissen, Nichtwissen, Unsicheres Wissen. Christoph Engel, Jost Halfmann and Martin Schulte. BadenBaden, Nomos: 305-350.

ENGEL, Christoph (2002c). Verhandelter Netzzugang. Baden-Baden, Nomos.

Engel, Christoph (2003). "Causes and Management of Conflicts." Journal of Institutional and Theoretical Economics 159: 1-15. 
Engel, Christoph (2004a). The Impact of Representation Norms on the Quality of Judicial Decisions. Max Planck Institute for Research on Collective Goods Preprint 2004/13. http://ssrn.com/abstract=617821.

Engel, Christoph (2004b). Inconsistency in the Law. In Search of a Balanced Norm. Preprints of the Max Planck Institute for Research on Collective Goods 2004/16. http://ssrn.com/abstract=628387.

Engel, Christoph (2004c). Learning the Law. Preprints of the Max Planck Institute for Research on Collective Goods Bonn 2004/5. http://ssrn.com/abstract=539982.

ENGEL, CHRISTOPH (2004d). Marktabgrenzung als soziale Konstruktion. Festschrift Immenga. Andreas Fuchs, Hans Peter Schwintowski and Daniel Zimmer. München, Beck: 127-147.

Engel, Christoph (2005). Generating Predictability. Institutional Analysis and Institutional Design. Cambrige, Cambridge University Press.

ENGEL, ChRISTOPH (2006). "Corporate Design for Regulability. A Principal-Agent-Supervisor Model." Journal of Institutional and Theoretical Economics 162: ***.

Engel, ChrIstoph and GÜNTER KnIEPs (1998). Die Vorschriften des Telekommunikationsgesetzes über den Zugang zu wesentlichen Leistungen. Eine juristisch-ökonomische Untersuchung. Baden-Baden, Nomos.

ENGISCH, KARL (1983). Einführung in das juristische Denken. Stuttgart, Kohlhammer.

Englich, BirTe and ThOmas Mussweiler (2001). "Sentencing under Uncertainty. Anchoring Effects in the Court Room." Journal of Applied Social Psychology 31: 1535-1551.

Evans, Jonathan St B. T., Julie L. Barston, et al. (1983). "On the Conflict between Logic and Belief in Syllogistic Reasoning." Memory and Cognition 11: 295-306.

Evans, Jonathan St B. T., Stephen E. Newstead, et al. (1993). Human Reasoning. The Psychology of Deduction. Hove ; Hillsdale (USA), Lawrence Erlbaum Associates.

FARnsworth, WARD (2000). Do Parties to Nuisance Cases Bargain After Judgement? A Glimpse into the Cathedral. Behavioral Law and Economics. Cass R. Sunstein. Cambridge, Cambridge University Press: 302-322.

FEHR, ERnST and Klaus M. SCHMidT (1999). "A Theory of Fairness, Competition, and Cooperation." Quarterly Journal of Economics 114: 817-868.

FEHR, ERnst and Klaus M. Schmidt (2000). Theories of Fairness and Reciprocity - Evidence and Economic Applications. CESifo Working Paper Series No. 403. http://papers.ssrn.com/paper.taf?abstract_id=255223. 
Feigenson, NeAL (2000). Legal Blame. How Jurors Think and Talk about Accidents. Washington, D.C., American Psychological Association.

FEZER, KARL-HeINZ (1986). "Aspekte einer Rechtskritik an der economic analysis of law und am property rights approach." Juristenzeitung 41: 817-824.

FEZER, KARL-Heinz (1988). "Nochmals: Kritik an der ökonomischen Analyse des Rechts." Juristenzeitung 43: 223-228.

FodOR, JERry A. (1983). The Modularity of Mind : an Essay on Faculty Psychology. Cambridge, Mass., MIT Press.

Ford, Kenneth M. and Zenon W. Pylyshyn (1996). The Robot's Dilemma Revisited. The Frame Problem in Artificial Intelligence. Norwood, N.J., Ablex Pub.

Frey, Bruno and Alois Stutzer (2001). Beyond Bentham - Measuring Procedural Utility. CESifo Working Papers 492. http://papers.ssrn.com/abstract=268059.

Friedman, Milton (1953). Essays in Positive Economics. [Chicago], University of Chicago Press.

Fudenberg, Drew and Jean Tirole (1991). Game Theory. Cambridge, Mass., MIT Press.

Gagarin, Michael (1994). Probability and Persuasion. Plato and Early Greek Rhetoric. Persuasion. Greek Rhetoric in Action. Ian Worthington. London, Routledge: 46-68.

GeERTZ, ClifFord (1983). Local Knowledge. Further Essays in Interpretive Anthropology. New York, Basic Books.

Gigerenzer, Gerd and Reinhard Selten, Eds. (2001). Bounded Rationality. The Adaptive Toolbox. Cambridge, MA, MIT Press.

Gigerenzer, Gerd, Peter M. Todd, et al. (1999). Simple Heuristics that Make us Smart. New York, Oxford University Press.

Glimcher, Paul W. (2003). Decisions, Uncertainty, and the Brain. The Science of Neuroeconomics. Cambridge, Mass., MIT Press.

Groot, Adrianus Dingeman DE (1965). Thought and Choice in Chess. The Hague, Mouton.

GRÖSCHNER, RolF (1998). Der homo oeconomicus und das Menschenbild des Grundgesetzes. Öffentliches Recht als ein Gegenstand ökonomischer Forschung. Die Begegnung der deutschen Staatsrechtslehre mit der Konstitutionellen Politischen Ökonomie. Christoph Engel and Martin Morlok. Tübingen, Mohr: 31-48.

Guthrie, Chris, JefFrey J. RachlinsKi, et al. (2001). "Inside the Judicial Mind." Cornell Law Review 86: 777-830. 
HALLERBACH, WinfRIED and JAAP SPRONK (2002). "AMultidimensional Framework for Financial-Economic Decisions." Journal of Multi-Criteria Decision Analysis 11: 111-124.

Halpern, Joseph Y. and David A. McAllester (1990). "Likelihood, Probability, and Knowledge." Computational Intelligence 5: 151-160.

Hammond, Kenneth R., Lewis O. Harvey, et al. (1992). "Making Better Use of Scientific Knowledge. Separating Truth from Justice." Psychological Science 3: 80-87.

Harless, David W. and Colin F. Camerer (1994). "The Predictive Utility of Generalized Expected Utility Theories." Econometrica 62: 1251-1289.

HARMAn, Gilbert (1965). "The Inference to the Best Explanation." Philosophical Review 74: 88-95.

Harman, Gilbert (1995). Rationality. Thinking. An Invitation to Cognitive Science III. Edward E. Smith and Daniel N. Osherson. Cambridge, Mass., MIT Press: 175-211.

Harman, Gilbert (2004). Practical Aspects of Theoretical Reasoning. Oxford Handbook of Rationality. Al Mele and Piers Rawling. Oxford, Oxford University Press: 45-56.

Hays, WiLliam LeE (1994). Statistics. Fort Worth, Harcourt College Publishers.

Heiner, RonAld A. (1983). "The Origin of Predictable Behavior." American Economic Review 73: 560-595.

HeinZerLing, LisA (1998). "Regulatory Costs of Mythic Proprotions." Yale Law Journal 107: 1981-2070.

Hellwig, Martin (2004). Risk Aversion in the Small and in the Large When Outcomes are Multidimensional. Preprints of the Max Planck Institute for Research on Collective Goods Bonn 2004/6. http://ssrn.com/abstract=567101.

Hildebrand, Doris (2002). The Role of Economic Analysis in the EC Competition Rules. The Hague; New York, Kluwer Law International.

Hinsz, Verlin B. and KRISTIN E. InDAHL (1995). "Assimilation to Anchors for Damage Awards in a Mock Civil Trial." Journal of Applied Social Psychology 25: 991-1026.

Hoffmann-Riem, Wolfgang (2001). "Sozialwissenschaften in der Rechtsanwendung - am Beispiel der Nutzung der Medienforschung in der Rechtsprechung zum Medienrecht." Zeitschrift für Rechtssoziologie 22: 1-22.

HofFMANN-RIEM, WolfGANG (2004). Methoden einer anwendungsorientierten Verwaltungsrechtswissenschaft. Methoden der Verwaltungsrechtswissenschaft. Eberhard SchmidtAßmann and Wolfgang Hoffmann-Riem. Baden-Baden, Nomos: 9-72. 
Hutter, Michael (1989). Die Produktion von Recht. Eine selbstreferentielle Theorie der Wirtschaft, angewandt auf den Fall des Arzneimittelpatentrechts. Tübingen, J.C.B. Mohr.

Johnson-LAird, PhiLiP N. (1989). Mental Models. Foundations of Cognitive Science. Michael Posner. Cambridge, Mass., MIT Press: 469-499.

Josephson, John R. and SusAn G. JosePhson (1994). Abductive Inference. Computation, Philosophy, Technology. Cambridge; New York, Cambridge University Press.

KeIL, Frank K. (2003). "Folkscience. Coarse Interpretations of a Complex Reality." Trends in Cognitive Science 7: 368-373.

Kelman, MarK (1987). A Guide to Critical Legal Studies. Cambridge, Mass., Harvard University Press.

Kelman, Mark, Yuval Rottenstreich, et al. (2000). Context-Dependence in Legal Decision Making. Behavioural Law and Economics. Cass R. Sunstein. Cambridge, Cambridge University Press: 61-94.

Kenny, Anthony (1978). Practical Reasoning and Rational Appetite. Practical Reasoning. Joseph Raz. Oxford, Oxford University Press: 63-80.

King, GARY, Robert O. KeOHANE, et al. (1994). Designing Social Inquiry. Scientific Inference in Qualitative Research. Princeton, N.J., Princeton University Press.

KirCHNER, CHRISTIAN (1991). "The Difficult Reception of Law and Economics in Germany." International Review of Law and Economics 11: 277-292.

Klerman, Daniel M. and Paul Mahoney (2004). The Value of Judicial Independence. Evidence from 18th Century England. http://ssrn.com/abstract=495642.

Knight, Frank Hyneman (1921). Risk, Uncertainty and Profit. Boston, New York,, Houghton Mifflin Company.

Koehler, Jonathan (2006). Train our Jurors. Heuristics and the Law. Christoph Engel and Gerd Gigerenzer. Cambridge, MIT Press: ***.

Koehler, Jonathan J. and DANIEL N. ShAVIRo (1990). "Veridical Verdicts. Increasing Verdict Accuracy through the Use of Overtly Probabilistic Evidence and Methods." Cornell Law Review 75: 247-279.

Kunn, Thomas S. (1962). The Structure of Scientific Revolutions. [Chicago], University of Chicago Press.

LAKOFF, GeORGE (1987). Women, Fire, and Dangerous Things. What Categories Reveal about the Mind. Chicago, University of Chicago Press. 
LANGerock, Hubert (1915). "Professionalism. A Study in Professional Deformation." American Journal of Sociology 21: 30-44.

LEAmer, Edward E. (1983). "Let's Take the Con out of Econometrics." American Economic Review 23: 31-43.

LePSIUS, OLIVER (2005). "Sozialwissenschaften im Verfassungsrecht - Amerika als Vorbild?" Juristenzeitung 60: 1-13.

LEVI, IsAAC (1962). "On the Seriousness of Mistakes." Philosophy of Science 29: 47-65.

Lovett, Marsha C. and John R. Anderson (2005). Thinking as a Production System. The Cambridge Handbook of Thinking and Reasoning. Keith J. Holyoak and Robert Morrison. Cambridge, Cambridge University Press: ***.

LuHMANN, NiKLAS (1986). Ökologische Kommunikation. Kann die moderne Gesellschaft sich auf ökologische Gefährdungen einstellen? Opladen, Westdeutscher Verlag.

LuHMANN, NiKLAS (1990). Die Wissenschaft der Gesellschaft. Frankfurt am Main, Suhrkamp.

LuHMANN, NiKLAS (1993). Das Recht der Gesellschaft. Frankfurt/Main, Suhrkamp.

MankTelow, Ken (2004). Reasoning and Rationality. The Pure and the Practical. Psychology of Reasoning. Theoretical and Historical Perspectives. Ken Manktelow and Man Cheung Chung. Hovy, Psychology Press: 157-177.

MAntZAvinos, Chrysostomos (2001). Individuals, Institutions, and Markets. Cambridge, UK, Cambridge University Press.

MantZavinos, Chrysostomos (2005). Naturalistic Hermeneutics. Cambridge, Cambridge University Press.

MARCh, JAmes G. and JOHAn P. Olsen (1989). Rediscovering Institutions. The Organizational Basis of Politics. New York, Free Press.

Mayer, Otто (1895). Deutsches Verwaltungsrecht. Leipzig,, Duncker \& Humblot.

McCaffery, Edward, Daniel Kahneman, et al. (2000). Framing the Jury. Cognitive Perspective on Pain and Suffering Awards. Behavioral Law and Economics. Cass R. Sunstein. Cambridge, Cambridge University Press: 259-287.

McCloskey, Deirdre N. (1998). The Rhetoric of Economics. Madison, Wis., University of Wisconsin Press.

McCloskey, Deirdre and Stephen Thomas Ziliak (2001). "The Standard Error of Regressions." Journal of Economic Literature: 97-114. 
McDermott, Drew V. (1987). "A Critique of Pure Peason." Computational Intelligence 3: 151160.

McGarity, Thomas O. (1998). "A Cost-Benefit State." Administrative Law Review 50: 7-79.

Meadow, William and Cass R. Sunstein (2001). "Statistics, not Experts." Duke Law Journal 51: 629-646.

Meyer, Philip N. (1994). "'Desperate for Love". Cinematic Influences upon a Defendant's Closing Argument to a Jury." Vermont Law Review 18: 721-749.

NG, Yew-KwANG (2003). Welfare Economics. Towards a More Complete Analysis. New York, Palgrave Macmillan.

Nisbett, Richard E., Kaiping Peng, et al. (2001). "Culture and Systems of Thought. Holistic Versus Analytic Cognition." Psychological Review 108: 291-310.

NitSCHE, RAineR and JUlia THIELERT (2004). "Die ökonomische Analyse auf dem Vormarsch Europäische Reform und deutsche Wettbewerbspolitik." Wirtschaft und Wettbewerb 54: 250-259.

OAKSFORD, M. and NICK CHATER (1998). Rationality in an Uncertain World: Essays on the Cognitive Science of Human Reasoning. Hove, East Sussex, UK, Psychology Press.

OTt, Claus and HANS-BERnd SCHÄFER (1988). "Die ökonomische Analyse des Rechts - Irrweg oder Chance wissenschaftlicher Erkenntnis ?" Juristenzeitung 43: 213-223.

Payne, John W., James R. Bettman, et al. (1988). "Adaptive Strategy Selection in Decision Making." Journal of Experimental Psychology 14: 534-552.

Pearl, Judea (1988). Probabilistic Reasoning in Intelligent Systems. Networks of Plausible Inference. San Mateo, Calif., Morgan Kaufmann Publishers.

Peirce, Charles S. and Kenneth Laine Ketner (1992). Reasoning and the Logic of Things. The Cambridge Conferences Lectures of 1898. Cambridge, Mass., Harvard University Press.

Pennington, NAnCy and Reid Hastie (1997). Explanation-Based Decision Making. Effects of Memory Structure on Judgement. Research in Judgement and Decision Making. William M. Goldstein and Robin M. Hogarth. Cambridge, Cambridge University Press: 454-481.

POPPER, KARL RAIMUND (1935). Logik der Forschung. Zur Erkenntnistheorie der modernen Naturwissenschaft. Wien, J. Springer.

Posner, ERIC A. (2000a). Law and Social Norms. Cambridge, Mass., Harvard University Press. 
Posner, Richard A. (2000b). "Cost-Benefit Analysis. Definition, Justification, and Comment on Conference-Papers." Journal of Legal Studies 29: 1153-1177.

Posner, Richard A. (2003). Economic Analysis of Law. New York, Aspen Publishers.

Posner, Richard A. and Andrew M. Rosenfield (1977). "Impossibility and Related Doctrines in Contract Law. An Economic Analysis." Journal of Legal Studies 6: 83-118.

Pylyshyn, Zenon W. (1987). The Robot's Dilemma. The Frame Problem in Artificial Intelligence. Norwood, N.J., Ablex.

RACHLinsKi, JEFFREY J. (2000). "Heuristics and Biases in the Courts. Ignorance or Adaptation?" Oregon Law Review 79: 61-102.

Rescher, Nicholas (1976). Plausible Reasoning. An Introduction to the Theory and Practice of Plausibilistic Inference. Assen, Van Gorcum.

Risse, Thomas (2000). "'Let's Argue!". Communicative Action in World Politics." International Organization 54: 1-39.

Schank, Roger C. and Robert P. Abelson (1977). Scripts, Plans, Goals, and Understanding. An Inquiry into Human Knowledge Structures. Hillsdale, N.J.; New York, L. Erlbaum Associates.

Scharpf, Fritz Wilhelm (1997). Games Real Actors Play. Actor-Centered Institutionalism in Policy Research. Boulder, Colo., Westview Press.

Schiavone, Aldo (1991). Der Jurist. Der Mensch der römischen Antike. Anrea Giardini. Frankfurt, Campus: 99-116.

SCHMIDT-AßMANN, EBERHARD (2004a). Das allgemeine Verwaltungsrecht als Ordnungsidee. Grundlagen und Aufgaben der verwaltungsrechtlichen Systembildung. Berlin, Springer.

SCHMIDT-AßMANN, EBERHARD (2004b). Methoden der Verwaltungsrechtswissenschaft - Perspektiven der Systembildung. Methoden der Verwaltungsrechtswissenschaft. Eberhard Schmidt-Aßmann and Wolfgang Hoffmann-Riem. Baden-Baden, Nomos: 387-413.

Schmidt-Aßmann, Eberhard and Wolfgang Hoffmann-Riem, Eds. (2004). Methoden der Verwaltungsrechtswissenschaft. Schriften zur Reform des Verwaltungsrechts ; 10. BadenBaden, Nomos.

Schulz, JoAchim (1992). Sachverhaltsfeststellung und Beweistheorie. Elemente einer Theorie strafprozessualer Sachverhaltsfeststellung. Köln, Heymanns.

Schulz, JoACHIM (2005). Rules of Evidence as Heuristics: Heuristics as Rules of Evidence. Heuristics and the Law. Christoph Engel and Gerd Gigerenzer. Boston, MIT Press: ***. 
SCHUPPERT, GUNNAR FOLKE (1993). Verwaltungsrechtswissenschaft als Steuerungswissenschaft. Zur Steuerung des Verwaltungshandelns durch Verwaltungsrecht. Reform des Allgemeinen Verwaltungsrechts. Grundfragen. Wolfgang Hoffmann-Riem, Eberhard SchmidtAßmann and Gunnar Folke Schuppert. Baden-Baden, Nomos: 65-114.

SEARLE, JoHn R. (2001). Rationality in Action. Cambridge, Mass., MIT Press.

Shapiro, Michael (1988). "Introduction: Judicial Selection and the Design of Clumsy Institutions." Southern California Law Review 61: 1555-1569.

Simon, Carl P. and Lawrence Blume (1994). Mathematics for Economists. New York, Norton.

Skinner, B. F. (1938). The Behavior of Organisms. An Experimental Analysis. New York, Appleton-Century.

Sloman, Steven A. (1993). "Feature-based Induction." Cognitive Psychology 25: 231-280.

SPENCER-BROwn, GEORGE (1969). Laws of Form. London,, Allen \& Unwin.

Stein, EDWARD (1996). Without Good Reason. The Rationality Debate in Philosophy and Cognitive Science. Oxford, Clarendon Press.

Steiner, Benjamin D., William J. Bowers, et al. (1999). "Folk Knowledge as Legal Action. Death Penalty Judgements and the Tenet of Early Release in a Culture of Mistrust and Punitiveness." Law and Society Review 33: 461-505.

Stich, Stephen P. (1990). The Fragmentation of Reason. Preface to a Pragmatic Theory of Cognitive Evaluation. Cambridge, Mass., MIT Press.

STRACK, FRITZ and RolAnd DEUTSCH (2002). Reflective and Impulsive Determinants of Social Behaviour.

Sunstein, CAss R., Ed. (2000a). Behavioral Law and Economics. Cambridge series on judgment and decision making. Cambridge England, Cambridge University Press.

Sunstein, Cass R. (2000b). Cost-Benefit Default Principles. Chicago John M. Olin Law \& Economics Working Paper 104. http://papers.ssrn.com/paper.taf?abstract_id=247884.

SurowieCKI, JAmES (2004). The Wisdom of Crowds. Why the Many Are Smarter Than the Few and How Collective Wisdom Shapes Business, Economies, Societies, and Nations. New York, Doubleday :.

Symposium (2000). "Cost-Benefit Analysis. Legal, Economic, and Philosophical Perspectives." Journal of Legal Studies 29: 837-1177. 
Thompson, Michael, Richard ElLis, et al. (1990). Cultural Theory. Boulder, Colo., Westview Press.

Tirole, JeAn (2002). "Rational Irrationality. Some Economics of Self-Management." European Economic Review 46: 633-655.

TURner, MARK (2001). Cognitive Dimensions of Social Science. New York, Oxford University Press.

Tversky, Amos and Itamar Simonson (1993). "Context-Dependent Preferences." Management Science 39: 117-185.

Tyler, Tom R. (1990). Why People Obey the Law. New Haven, Yale University Press.

VAn AAKen, Anne (2003). "Rational Choice" in der Rechtswissenschaft. Zum Stellenwert der ökonomischen Theorie des Rechts. Baden-Baden, Nomos.

VISCUSI, W.KIP (2001). "Jurors, Judges, and the Mistreatment of Risk by the Courts." Journal of Legal Studies 30: 107-142.

Walton, Douglas N. (1996). Argumentation Schemes for Presumptive Reasoning. Mahwah, N.J., L. Erlbaum Associates.

Walton, Douglas N. (2001). "Abductive, Presumptive and Plausible Arguments." Informal Logic 21: 141-169.

Weber, Elke U. and Patrizia G. Lindemann (2002). Decision Modes or Choosing how to Choose. Making Decisions with our Head, our Heart, or by the Book

WeBer, MAX (1967). Wissenschaft als Beruf. Berlin, Duncker \& Humblot.

WiLkins, Minna C. (1928). "The Effect of Changed Material on Ability to Do Syllogistic Reasoning." Archives of Psychology 102: 83.

ZIMAN, J. M. (2000). Real Science. What it Is, and What it Means. Cambridge ; New York, Cambridge University Press. 